\title{
VIZURA HRVATSKOG MALOLJETNIČKOG KAZNENOG PRAVA PRI ODLUČIVANJU O MALOLJETNIČKOM ZATVORU I NJEGOVU PRIDRŽAJU - POSTOJE LI KRITERIJI ILI JE SVE DISKRECIJSKA ODLUKA SUDA
}

\author{
Izv. prof. dr. sc. Marta Dragičević Prtenjača* \\ Dr. sc. Reana Bezić** \\ Dr. sc. Marina Zagorec ***
}

UDK: 343.811-053.6(497.5)

$343.137 .5(497.5)$

DOI: 10.3935/zpfz.71.34.03

Izvorni znanstveni rad

Primljeno: kolovoz 2021.

Sudovi za mladež diljem Hrvatske izriču sankcije maloljetnim počiniteljima kaznenih djela (maloljetnicima). Pri odlučivanju i odabiru sankcije imaju velike diskrecijske ovlasti što posljedično može dovesti i do neujednačenosti sudske prakse u maloljetničkom kaznenom pravu. Posebno se spornim pokazalo pitanje odlučivanja o primjeni maloljetničkog zatvora (koji se primjenjuje ultima ratio) te njegove modifikacije - pridržaja maloljetničkog zatvora. Stoga se u radu istraživanjem nastojalo razmotriti i uvidjeti postoje li određeni formalni kriteriji za razgraničenje pri odabiru primjene maloljetničkog zatvora od njegova pridržaja, odnosno kriteriji kojima se suci vode pri odlučivanju kada i u kojim slučajevima primijeniti maloljetnički zatvor, a kada njegov pridržaj. Slijedom toga, postavljena je i hipoteza $(H)$ : Postoje kriteriji za razgraničenje primjene maloljetničkog zatvora od

* Dr. sc. Marta Dragičević Prtenjača, izvanredna profesorica Pravnog fakulteta Sveučilišta u Zagrebu, Trg Republike Hrvatske 14, 10000 Zagreb; marta.dragicevic@ pravo.hr;

ORCID ID: orcid.org/0000-0001-9666-4765

** Dr. sc. Reana Bezić, asistentica Pravnog fakulteta Sveučilišta u Zagrebu, Trg Republike Hrvatske 14, 10000 Zagreb; rbezic@pravo.hr; ORCID ID: orcid.org/0000-0002-1299-0860

**** Dr. sc. Marina Zagorec, pročelnica Gradskog ureda za imovinsko-pravne poslove, Grad Zagreb, Trg Stjepana Radića 1, 10000 Zagreb; marina.zagorec@zagreb.hr; ORCID ID: orcid.org/0000-0001-9392-8155 
pridržaja maloljetničkog zatvora. Za provjeru hipoteze u istraživanju se koristila normativno-deskriptivna, kvalitativna i deskriptivna analiza.

Ključne riječi: maloljetnički zatvor, pridržaj maloljetničkog zatvora, odmjeravanje kazne, diskrecijska ovlast suda

\section{UVODNO O KAZNENOJ ODGOVORNOSTI MALOLJETNIKA}

Djeca koja ostvaruju obilježja kaznenih djela zbog svoje ranjivosti, nezrelosti i drugih različitosti u odnosu na punoljetne, odrasle počinitelje imaju poseban položaj, pa i zaštitu u kaznenom pravu. Odbor za prava djeteta UN-a ${ }^{1}$ iznio je stajalište da se djeca razlikuju od odraslih počinitelja kaznenih djela ne samo u psihofizičkom razvoju, nego i drugim potrebama, primjerice emocionalnim i obrazovnim, što sve utječe na drukčiji tretman djece kao počinitelja kaznenih djela i predstavlja osnovu za njihovu smanjenu odgovornost. ${ }^{2}$ Upravo je dob djeteta u većini sustava prevalentan kriterij kaznene odgovornosti i primjene maloljetničkog kaznenog prava. Ispod određene granične dobi osobe se u (maloljetničkom) kaznenom pravu smatraju djecom i izuzeta su od kaznene odgovornosti ${ }^{3}$, dok se od te granične dobi do punoljetnosti smatraju maloljetnicima. ${ }^{4}$ Scott i Steinberg navode da su maloljetnici nezreli i rijetko razmišljaju o posljedicama svojih postupaka, koje su često produkt brzopletosti, nepromišljenosti

1 Više o Odboru za prava djeteta UN-a vidi na: https://www.ohchr.org/en/hrbodies/ crc/pages/crcindex.aspx (8. kolovoza 2021.).

2 Opća preporuka br. 10, CRC/C/GC/10, 25. travnja 2007., par. 10, str. 5; dostupna na: https://www2.ohchr.org/english/bodies/crc/docs/CRC.C.GC.10.pdf (10. lipnja 2020.).

3 U Hrvatskoj su prepuštena obiteljskom pravu, pa čak ako ostvare obilježja teških kaznenih djela (npr. ubojstvo).

Dragičević Prtenjača, M.; Bezić, R., Perspektiva uvođenja doktrine doli incapax u hrvatsko maloljetničko kazneno pravo, Macedonian Journal for Criminal Law and Criminology, vol. 25, br. 1, 2018., str. 25.

4 U Hrvatskoj je dob kaznenopravne odgovornosti apsolutno određena na 14 godina, tako da su maloljetnici osobe koje su počinile kaznena djela u dobi od navršenih 14 godina do nenavršenih 18 godina - čl. 2. Zakona o sudovima za mladež, Narodne novine, br. 84/11, 143/12, 148/13, 56/15, 126/19. Dijele se u dvije potkategorije, na mlađe maloljetnike (14 - 16) i na starije maloljetnike (16 - 18). Cvjetko, B., Criminal Responsibility of Minors in the Republic of Croatia, Revue internationale de droit pénal, vol. 75, br. 1-2, 2004., str. 263 - 275; dostupno na: https://www.cairn.info/ revue-internationale-de-droit-penal-2004-1-page-263.htm\# (9. lipnja 2020.). Vidi i Cvjetko, B.; Singer, M., Kaznenopravna odgovornost mladeži u praksi i teoriji, Organizator, Zagreb, 2011., str. 85. 
i jednostavno dokazivanja vršnjacima. ${ }^{5}$ Skloni su rizičnim ponašanjima koja su nerijetko impulzivna i uvjetovana željom za pripadnošću skupini. ${ }^{6}$ Time se opravdava poseban sustav maloljetničkog sudovanja i drukčiji odnos prema djeci 'počiniteljima' kaznenih djela, među ostalim i uvođenjem sankcija različitih od

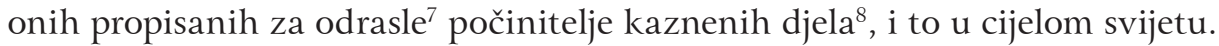

Svakoj državi ostavljeno je na volju kolika će biti minimalna dob kaznene odgovornosti, a tako i kolika je dob punoljetnosti osobe. ${ }^{9}$ Tijekom povijesti položaj maloljetnika u kaznenom pravu mijenjao se ovisno o prevladavajućim shvaćanjima društva tog vremena. Jedno se vrijeme na djecu kao počinitelje gledalo kao na zločince u minijaturi ${ }^{10}$, ali se danas u Hrvatskoj, pa i u svijetu smatra da djeca zbog svojih specifičnosti u odnosu na odrasle, punoljetne počinitelje imaju pravo na drukčiji (povoljniji) tretman ponajprije usmjeren na

5 Scott, E.; Steinberg, L., Adolescent Development and the Regulation of Youth Crime, The Future of Children: Juvenile Justice, vol. 18, br. 2, 2008., str. 15 - 33.

6 Ibid

7 Pojam odraslih počinitelja kaznenih djela obuhvaća osobe od navršene 21 godine života jer se prema mlađim punoljetnicima, odnosno osobama od navršenih 18 do nenavršene 21 godine života može djelomično primjenjivati i maloljetničko kazneno pravo, preciznije neka procesna prava i maloljetničke sankcije, pa je takav režim svojevrsni prijelaz iz maloljetničke odgovornosti u punoljetničku, a odluku o tome hoće li se primjenjivati maloljetničko kazneno pravo ili opće kazneno pravo opet je u diskrecijskoj ovlasti suda.

8 Odbor za prava djeteta osnovan je radi utvrđivanja ostvarenog napretka država stranaka u postizanju i ispunjavanju obveza prihvaćenih u Konvenciji, Opća preporuka br. 10, CRC/C/GC/10, 25. travnja 2007., par. 10, str. 5; dostupna na: https:// www2.ohchr.org/english/bodies/crc/docs/CRC.C.GC.10.pdf (10. lipnja 2020.).

9 Što je i u skladu s Konvencijom o pravima djeteta koja propisuje da “dijete označava svaku osobu mlađu od 18 godina, osim ako se zakonom koji se primjenjuje na dijete granica punoljetnosti ne odredi ranije." (čl. 1. Konvencije).

10 Carić, A., Mlađe osobe u kaznenom pravu (počinitelji i žrtve), Pravni fakultet Sveučilišta u Zagrebu, Zagreb, 2002., str. 1; Rittossa, D.; Božićević-Grbić, M., Zakon o sudovima za mladež - reformski zahvati i praktične dileme, Hrvatski ljetopis za kazneno pravo i praksu, vol. 19, br. 2, 2012., str. 616; Ivičević Karas, E.; Munivrana Vajda, M., Kazneno pravo i djeca, u: Hrabar, D. (ur.), Prava djece - multidisciplinaran pristup, Pravni fakultet Sveučilišta u Zagrebu, Zagreb, 2016., str. 165. Više o povijesnom razvoju vidi i: Bojanić, I., Croatia, u: Dünkel, F.; Grzywa, J.; Horsfield, P.; Pruin, I. (ur.), Juvenile Justice Systems in Europe - Current Situation and Reform Developments, vol. 1, Forum Verlag Godesberg, Mönchengladbach, 2011., str. 187 - 190 i Dragičević Prtenjača; Bezić, op. cit. u bilj. 3, str. $1-37$. 
njihov preodgoj u situacijama kada su počinila kaznena djela. ${ }^{11}$ Tako se razvio i poseban dio kaznenog prava (materijalnog i procesnog), tzv. maloljetničko kazneno pravo (engl. juvenile justice ili juvenile penal law; fr. droit penal juvenil; njem. Jugendstrafrecht; tal. diritto penale juvenile $)^{12} \mathrm{~s}$ posebnim materijalnim i postupovnim pravilima te sustavom sankcija, koje je u Hrvatskoj ponajprije regulirano Zakonom o sudovima za mladež (dalje u tekstu: $Z S M$ ) ${ }^{13}$, ali se podredno primjenjuju i Kazneni zakon (dalje u tekstu: KZ) ${ }^{14}$ te Zakon o kaznenom postupku (dalje u tekstu: ZKP) $)^{15}$.

Potrebno je istaknuti kako neke države, pa i Hrvatska, poznaju još jednu posebnu kategoriju počinitelja kaznenih djela - mlađe punoljetnike, koji su svojevrstan most između maloljetništva i odrasle dobi, te i za njih postoje posebnosti u primjeni materijalnog i postupovnog kaznenog prava u odnosu na odrasle osobe. Potonji su osobe od navršene godine punoljetnosti pa obično još dvije-tri godine nakon toga. ${ }^{16}$

Poseban položaj i tretman mladih počinitelja kaznenih djela (maloljetnika i mlađih punoljetnika) u kaznenom pravu reguliran je nizom međunarodnih

11 Božićević-Grbić, M.; Roksandić Vidlička, S., Reforma maloljetničkog kaznenog prava i sudovanja, Hrvatski ljetopis za kazneno pravo i praksu, vol. 18, br. 2, 2011., str. 687 - 702 , str. 679 - 715.

12 Horvatić, Ž., Rječnik kaznenog prava, Masmedia, Zagreb, 2002., str. 233.

13 Zakon o sudovima za mladež, Narodne novine, br. 84/2011, 143/2012, 148/2013, 56/2015, 126/2019.

14 Kazneni zakon, Narodne novine, br. 125/2011, 144/2012, 56/2015, 61/2015, 101/2017, 118/2018, 126/2019, 84/2021.

15 Zakon o kaznenom postupku, Narodne novine, br. 152/2008, 76/2009, 80/2011, 121/2011, 91/2012, 143/2012, 56/2013, 145/2013, 152/2014, 70/2017, 126/2019.

16 U Hrvatskoj su to (punoljetne) osobe od 18. do nenavršene 21. godine života; čl. 2. ZSM-a. 
dokumenata na razini Ujedinjenih naroda ${ }^{17}$, Europske unije ${ }^{18}$ i Vijeća Europe ${ }^{19}$, od kojih su neki obligatorni, a drugi su tzv. soft law dokumenti. ${ }^{20}$

17 Jedan od najvažnijih dokumentna s područja zaštite dječjih prava je Konvencija o pravima djeteta iz 1989., koja sveobuhvatno regulira prava djece kada su ona žrtve kaznenih djela ili kada su ona sama počinitelji kaznenih djela; za više vidi: https:// www.ohchr.org/en/professionalinterest/pages/crc.aspx (8. lipnja 2021.) ili https:// www.unicef.hr/wp-content/uploads/2017/05/Konvencija_20o_20pravima_20djeteta_full.pdf (27. srpnja 2021.); Smjernice UN-a o pravosuđu u predmetima koji uključuju djecu kao žrtve i svjedoke kaznenih djela - Rezolucija Gospodarskog i socijalnog vijeća 2005/20 i dr.

18 Direktiva (EU) 2011/93 Europskog parlamenta i Vijeća o suzbijanju seksualnog zlostavljanja i seksualnog iskorištavanja djece i dječje pornografije. Direktive koje se također primjenjuju na djecu jesu: Direktiva 2012/29/EU, usvojena s ciljem uspostave minimalnih standarda za potporu, prava i zaštitu žrtava kaznenih djela; Direktiva 2012/13/EU propisuje minimalna pravila u pogledu informiranja o pravima osumnjičenika ili okrivljenika; Direktiva 2013/48/EU povezana je s prethodno spomenutom Direktivom (Direktiva 2012/13) jer mora odmah primiti informacije o pravu na pristup odvjetniku te da osumnjičenik ili optuženik koji su uhićeni ili pritvoreni odmah prime obavijest u pisanom obliku o pravima koja sadržavaju informacije o pravu na pristup odvjetniku.

19 Europska konvencija za zaštitu ljudskih prava i temeljenih sloboda, Narodne novine, br. 18/1997, 6/1999, 14/2002, 13/2003, 9/2005, 1/2006, 2/2010; Preporuka Vijeća ministara Rec(2005)5 o pravima djece koja žive u ustanovama; Rezolucija 1530(2007) o djeci žrtvama kaznenih djela: suzbijanje svih oblika nasilja, izrabljivanja i zlouporaba (VE).

20 Standardna minimalna pravila UN-a za provođenje sudskih postupaka prema maloljetnicima, tzv. Pekinška pravila (1985), A/RES/40/33; dostupno na: https://www. refworld.org/docid/3b00f2203c.html (10. lipnja 2020.); Smjernice UN-a za prevenciju maloljetničke delinkvencije - "Rijadske smjernice" (1990.); Pravila UN-a za zaštitu maloljetnika lišenih slobode - "Havanska ili JDL pravila” (1990.); Preporuka Vijeća ministara Rec(2003)20 o novim načinima suočavanja s maloljetničkom delinkvencijom i ulogom maloljetničkog pravosuđa (VE); Preporuka Vijeća ministara CM/Rec (2008)11 o Europskim pravilima za maloljetne prijestupnike osuđene na sankcije ili mjere (VE); Smjernice Vijeća ministara (VE) o pravosuđu prilagođenom djeci (Guidelines of the Committee of Ministers of the Council of Europe on child-friendly justice) iz 2010.; Direktiva (EU)2016/800 Europskog parlamenta i Vijeća (11. svibnja 2016.) o postupovnim jamstvima za djecu koja su osumnjičenici ili optuženici u kaznenim postupcima. 


\section{1.l. Ukratko o maloljetničkim sankcijama i njihovoj svrsi u hrvatskom kaznenom pravu}

Hrvatski kaznenopravni sustav propisuje niz sankcija za počinjeno kazneno djelo $^{21}$, ali se one razlikuju ovisno o tome primjenjuju li se prema punoljetnim, tj. odraslim počiniteljima kaznenih djela ili maloljetnicima. U Hrvatskoj su maloljetničke sankcije odgojne mjere, maloljetnički zatvor i sigurnosne mjere, a najzastupljenije su u praksi odgojne mjere (ima ih osam).$^{22}$ Prema posljednjim dostupnim podacima od odgojnih mjera najzastupljenije su mjere pojačane brige i nadzora s $35 \%$ (2020.), zatim mjere upozorenja (sudski ukor i posebne obveze) s 33,2 \% (2020.). ${ }^{23}$ Određene se sankcije mogu izreći samo pojedinoj kategoriji maloljetnih počinitelja. I dok se odgojne mjere mogu izreći svim maloljetnim počiniteljima kaznenih djela, maloljetnički zatvor i njegov pridržaj mogu se izreći samo starijim maloljetnicima (16 - 18). ${ }^{24}$ Maloljetnički zatvor ima se primjenjivati ultima ratio (kao krajnje sredstvo), što je nedvojbeno slučaj i u hrvatskoj praksi jer iz posljednjih dostupnih statističkih podataka (2020.) proizlazi da se izriče u samo $3 \%$, dok se pridržaj izriče u nešto većem postotku od 15,3\% (2020.). ${ }^{25}$

U vezi s različitosti spektra sankcija koje se mogu izreći maloljetnicima u odnosu na punoljetne, odrasle počinitelje razlikuje se i svrha maloljetničkih sankcija, odnosno svrha kažnjavanja maloljetnika u odnosu na svrhu kažnjavanja odraslih počinitelja kaznenih djela. ${ }^{26}$ Izricanjem sankcija maloljetnicima nastoji se ostvariti ponajprije preodgoj i postići specijalnopreventivna svrha ${ }^{27}$, a u pogledu nekih sankcija, kao primjerice maloljetničkog zatvora, i general-

21 Čl. 40. KZ-a i čl. 5. ZSM-a.

22 Sudski ukor; posebne obveze; pojačana briga i nadzor; pojačana briga i nadzor uz dnevni boravak u odgojnoj ustanovi; upućivanje u disciplinski centar; upućivanje $\mathrm{u}$ odgojnu ustanovu; upućivanje u odgojni zavod; upućivanje u posebnu odgojnu ustanovu. Više vidi u: Radić, I., Sustav maloljetničkih sankcija, doktorska disertacija, Pravni fakultet Sveučilišta u Zagrebu, Zagreb, 2016.

23 Državni zavod za statistiku, Baza podataka, dostupno na: https://www.dzs.hr (8. kolovoza 2021.).

24 Isto navodi i Bojanić u: Bojanić, op. cit. u bilj. 10, str. 188.

25 Ibid.

26 Za više o svrsi kažnjavanja vidi: Cvitanović, L., Svrha kažnjavanja u suvremenom kaznenom pravu, Hrvatsko udruženje za kaznenopravne znanosti i praksu, Zagreb, 1999.

27 Čl. 6. st. 1. ZSM-a. Želi se utjecati na maloljetnikov “odgoj, razvijanje njegove cjelokupne ličnosti i jačanje njegove osobne odgovornosti radi suzdržavanja od ponovnog činjenja kaznenih djela", i to ponajprije "pružanjem zaštite, brige, pomoći i nadzora te osiguranjem opće i stručne naobrazbe maloljetnog počinitelja kaznenog djela." Više vidi u: Cvjetko, op. cit. u bilj. 4, str. 263. 
nopreventivna. ${ }^{28}$ Međutim, retribuciji, odnosno represivnom elementu koji je karakteristika svrhe kažnjavanja ${ }^{29}$ kod odraslih počinitelja nema mjesta $\mathrm{u}$ maloljetničkom pravu.

Odbor za prava djeteta u Općoj preporuci br. 10 jasno je dao do znanja da se primat represije i retribucije, koja je inače karakteristična za kazneno pravo, mora zamijeniti preventivnim elementima svrhe kažnjavanja, naravno, u skladu s najboljim interesom djeteta ${ }^{30}$ kada su u pitanju djeca počinitelji kaznenih djela. Navedeno bi se trebalo provesti u cilju postizanja što funkcionalnije rehabilitacije djeteta te ciljeva restorativne pravde. ${ }^{31} \mathrm{U}$ srži takvog shvaćanja je upravo načelo najboljeg interesa djeteta ${ }^{32}$, što bi i inače trebala biti okosnica postupanja prema maloljetnim počiniteljima kaznenih djela. ${ }^{33}$ Takve stavove zastupao je i Frank još davnih 50-ih godina 20. stoljeća, razlikujući duševno razvijene maloljetnike kojima se može izreći kazna koja je primarno usmjerena na njihov odgoj i duševno nerazvijene ili ‘socijalno zapuštene' maloljetnike kojima se ne bi mogla izreći kazna, ali bi ‘odgojnopopravne’ mjere koje su usmjerene na odgoj počinitelja i razvoj njegove ličnosti. ${ }^{34}$

\subsection{O maloljetnim počiniteljima, tj. osuđenicima i zatvorenicima u Europi}

U Europi trenutačno prevladava trend da se maloljetnički zatvor uistinu primjenjuje samo kao krajnja mjera. Prema posljednjim dostupnim podacima

28 Čl. 6. st. 2. ZSM-a.

29 Čl. 41. KZ-a.

30 Više o najboljem interesu maloljetnika u kaznenom pravu vidi u: Lechner, S., Najbolji interes maloljetnika u kaznenom pravu, završni specijalistički rad, Pravni fakultet Sveučilišta u Zagrebu, Zagreb, 2021.

31 Opća preporuka br. 10, CRC/C/GC/10, 25. travnja 2007., par. 10, str. 5; dostupna na: https://www2.ohchr.org/english/bodies/crc/docs/CRC.C.GC.10.pdf (10. lipnja 2021.).

32 Više o polemici o pojmu najboljeg interesa djeteta vidi u: Božićević-Grbić; Roksandić Vidlička, op. cit. u bilj. 11, str. 680 - 687 i Zagorec, M., Problematika postupanja prema maloljetnim počiniteljima kaznenih djela, Policija i sigurnost, vol. 26, br. 4, 2017. str. 283 - 301 .

33 Opća preporuka br. 10, par. 10, str. 5.

34 Frank, S., Kazneno pravo, Izdavački zavod Jugoslavenske akademije znanosti i umjetnosti, Zagreb, 1950., str. 36. Više u: Radić, I., Hrvatski sustav maloljetničkih sankcija: trenutačno stanje i prijedlozi za promjenu, Hrvatski ljetopis za kaznene znanosti i praksu, vol. 24, br. 1, 2017., str. 83 - 115. 
(2016. god.) European Sourcebook of Crime and Criminal Justice Statistics $2021^{35} \mathrm{u}$ grafu 1 prikazan je iznimno mali udio maloljetnika u zatvorskoj populaciji na razini cijele Europe, dok u ukupnoj osuđeničkoj populaciji broj varira među prikazanim državama. ${ }^{36}$

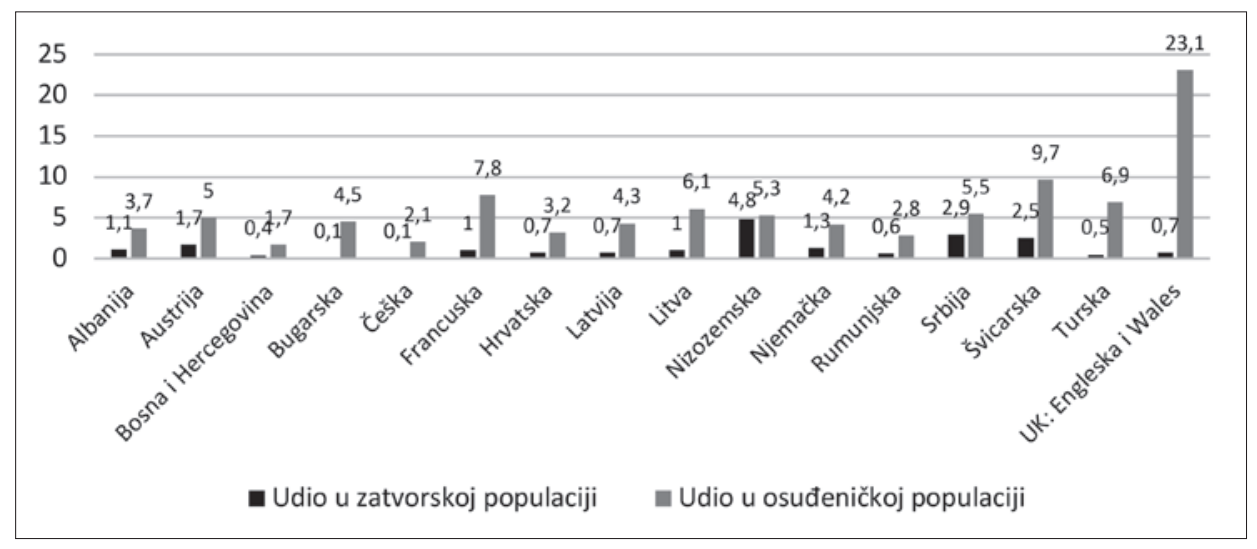

Graf 1: Udio maloljetnika u odabranim državama u ukupnoj zatvorskoj i osuđeničkoj populaciji u 2016. godini ${ }^{37}$

Najveći udio maloljetnika u ukupnoj osuđeničkoj populaciji premoćno imaju Engleska i Wales s čak 23,1 \% osuđenih maloljetnika. Slijedi Švicarska $(9,7$ \%) i Francuska (7,8 \%). Najmanji udio maloljetnika u ukupnoj osuđeničkoj populaciji nalazi se u Češkoj (2,1 \%), dok se Hrvatska svrstava među zemlje s malim udjelom maloljetnika, tj. s udjelom od 3,2\%. Prema dostupnim podacima o udjelu maloljetnika u ukupnoj zatvorskoj populaciji, taj udio u Češkoj i Bugarskoj je ispod 0,2 \%. Hrvatska se uz Latviju i Rumunjsku nalazi unutar europskog pro-

35 Aebi, M. F.; Caneppele, S.; Hashimoto, Y. Z.; Jehle, J.-M.; Khan, T. S.; Kühn, O.; Lewis, C.; Molnar, L.; Pórisdóttir, R.; Smit, P.; national correspondents, European Sourcebook of Crime and Criminal Justice Statistics 2021, Series UNILCRIM, 2021., str. 175 i 268; dostupno na: https://wp.unil.ch/europeansourcebook/printed-editions-2/ (1. lipnja 2021.).

36 U grafu I prikazan je udio maloljetnika u ukupnom broju zatvorenika na određeni dan u godini, tj. stock podaci (npr. za Hrvatsku su dostupni podaci o ukupnom broju zatvorenika na dan 31. prosinca, dok druge zemlje mogu imati kao referentni datum neki drugi npr. 1.9. itd.), te udio maloljetnika u ukupnom broju osuđenih osoba (i punoljetnih i maloljetnih) u jednoj godini.

37 Aebi et al., op. cit. u bilj. 35, str. 268. Željelo se vidjeti kakvo je stanje u zatvoreničkoj i osuđeničkoj populaciji maloljetnika u zemljama bivših komunističkih režima, zapadnoeuropskih država, zemalja EU-a, Švicarske i zemalja pripadnica anglosaksonskog sustava. 
sjeka s rasponom od 0,6\% do 0,7 \% udjela maloljetnika u zatvorskoj populaciji. Nizozemska zauzima vodeće mjesto s udjelom od čak 4,8 \%, slijedi Srbija s $2,9 \%$ te Švicarska s 2,5 \%. Većina europskih zemalja ima manje od 1 \% udjela maloljetnika u ukupnoj zatvorskoj populaciji.

Usporedbom udjela maloljetnika koji se nalaze u zatvorima i udjela ukupno osuđenih maloljetnika vidi se da je udio maloljetnika koji se nalaze u zatvorima do nekoliko puta manji od udjela osuđenih maloljetnika. To je važno zato što se jasno vidi da se maloljetnički zatvor očito primjenjuje u manjem broju slučajeva u odnosu na druge sankcije.

Iznimka su jedino Srbija i Nizozemska u kojima su ta dva udjela (maloljetnički zatvor / ukupne osude) slična, odnosno to upućuje da će velik broj osuđenih maloljetnika dobiti i zatvorsku sankciju. Ipak, iz navedenih podataka vidljivo je da se u velikoj većini europskih država maloljetnički zatvor primjenjuje samo kao krajnja mjera. Što je stvarni uzrok tome, ne može se sa sigurnošću zaključiti, ali u obzir dolaze razne mogućnosti i faktori, različite fenomenologije kaznenih djela, strože politike kažnjavanja, drukčiji normativni okviri, razlika u tamnoj brojci $^{38}$ itd.

Fagan i Kupchik ${ }^{39}$ iznijeli su stajalište da se danas maloljetnički zatvor u većini europskih država primjenjuje kao krajnja mjera zbog toga što je dolazilo do pretjeranog zatvaranja maloljetnika, odnosno situacije kakva je očito danas u Nizozemskoj i Srbiji. S vremenom se nastojalo da se primjena takvih sankcija svede na minimum, kako to ističu Van der Laan i Eichelsheim. ${ }^{40}$ Primjerice, $\mathrm{u}$ Nizozemskoj je 2010. bilo oko 4000 maloljetnika u zatvoru. ${ }^{41}$

38 Više vidi u: Getoš Kalac, A.; Pribisalić, D., Tamna i svijetla strana tamne brojke kriminala: o izazovima istraživanja nepoznanica i blagoslovu neznanja, Zbornik Pravnog fakulteta u Zagrebu, vol. 70, br. 5, 2020., str. 637 - 673, https://doi.org/10.3935/zpfz.70.5.03.

39 Fagan, J.; Kupchik, A., Juvenile Incarceration and the Pains of Imprisonment, Duke Forum for Law \& Social Change, vol. 3, br. 29, 2011., str. 30 - 32; dostupno na: https://heinonline.org/HOL/Page?collection=journals \& handle=hein.journals/dukef3\&id=32\&men_tab=srchresults (28. srpnja 2020.).

40 Van der Laan, A.; Eichelsheim, V., Juvenile Adaptation to Imprisonment: Feelings of Safety, Autonomy and Well-Being, and Behaviour in Prison, European Journal of Criminology, vol. 10, br. 4, 2013., str. 425; dostupno na: https://heinonline.org/HOL/Page?collection $=$ journals\& handle $=$ hein.journals/eujcrim $10 \& i d=423 \&$ men_tab $=$ srchresults (28. srpnja 2020.).

41 Ibid. Tada je Nizozemska bila četiri puta veća od Hrvatske sa stanovništvom preko 16 milijuna. Informacije dostupne na: https://www.enciklopedija.hr/natuknica.aspx?id=43943\# poglavlje10248 (28. srpnja 2020.). 
Izgleda kako se u Hrvatskoj, prema DZS-ovim podacima ${ }^{42}$, krenulo suprotnim smjerom i otišlo u drugu krajnost koja je rezultirala vrlo blagim kažnjavanjem maloljetnika, a u većini slučajeva nije bio proveden ni neformalni kazneni postupak (propisan ZSM-om) prema maloljetnicima (zbog načela svrhovitosti). ${ }^{43}$ Ako je politika kažnjavanja preblaga, može doći upravo do kontraefekta i do, kako to ističe Radić, tzv. kulture neodgovornosti ${ }^{44}$, pa, napominje Ricijaš, treba razviti dobru "politiku sankcioniranja počinitelja kaznenih djela." ${ }^{" 45}$ Ako politika kažnjavanja nije dobra, i u tom smislu preblaga, pa ni sankcija nije pravilno određena i odmjerena, kod maloljetnika se može javiti sindrom kako sam se izvukao te postati dinamički rizični čimbenik ${ }^{46} \mathrm{i}$ ohrabriti ih u daljnjem počinjenju kaznenih djela.

\subsection{Crtice o sustavima kaznene odgovornosti mladih počinitelja u svijetu i minimalnoj dobi kaznene odgovornosti}

Sustavi kaznene odgovornosti i sustavi sankcija razlikuju se u svijetu. U većini država (pa tako i u Hrvatskoj) ${ }^{47}$ prihvaćen je tzv. welfare approach. Riječ je o državama koje imaju uveden tzv. welfare system ili sustav koji je prilagođen djeci i orijentiran na njihovu dobrobit, odnosno postupanje u najboljem djetetovu interesu (osim Austrije i Velike Britanije) ${ }^{48}$, s velikom lepezom formalnih

42 Mišljenje se temelji na podacima DZS-a, iz kojih proizlazi da je načelo svrhovitosti u približno $55 \%$, a maloljetnički zatvor u prosjeku $3 \%$, iz čega proizlazi da se u stvari blago kažnjava.

43 U Hrvatskoj se u velikoj mjeri koristi načelo svrhovitosti (gotovo $50 \%$; 53 \% u 2018. god.). U 2018. godini od ukupnog broja prijavljenih kaznenih djela koja su počinili maloljetnici (1196) u čak 53 \% slučajeva nije bio pokrenut postupak (636) iz razloga svrhovitosti. Izvješće Državnog zavoda za statistiku (dalje u tekstu: DZS), br. 1651/2019, Maloljetni počinitelji kaznenih djela, prijave, optužbe i osude u 2018., str. 14 i 15, odnosno 48 \% u 2019. U 2019. godini od ukupnog broja prijavljenih kaznenih djela koja su počinili maloljetnici (1213) u čak 48 \% slučajeva nije bio pokrenut postupak (577) zbog primjene načela svrhovitosti. Priopćenje - Maloljetni počinitelji kaznenih djela prema vrsti odluke u 2019. Više o načelu svrhovitosti u: Puharić, B.; Radić, I., Primjena načela svrhovitosti u postupanju prema maloljetnicima, Hrvatski ljetopis za kazneno pravo i praksu, vol. 22, br. 2, 2015., str. 635 - 670.

44 Radić, op. cit. u bilj. 34, str. 84.

45 Ricijaš, N., Atribuiranje vlastitog delinkventnog ponašanja nisko rizičnih i visoko rizičnih maloljetnih delikvenata, Kriminologija i socijalna integracija, vol. 17, br. 1., 2009., str. 17.

46 Više o tom pojmu vidi u: Ricijaš, op. cit. u bilj. 45, str. 16.

47 Radić, op. cit. u bilj. 34, str. 85.

48 Dragičević Prtenjača; Bezić, op. cit. u bilj. 3, str. 32. 
i neformalnih sankcija te kaznenim postupkom prilagođenim djeci, kao i predviđenim alternativnim rješenjima. ${ }^{49}$ Pojedine države, ističe Radićs ${ }^{50}$, naglasak su stavile na neoliberalni koncept i zaoštravanje politike kažnjavanja prema maloljetnicima (npr. Engleska, Wales i Francuska), dok su druge države (npr. Švicarska, skandinavske zemlje, Njemačka i dr.) ipak više usmjerene na odgojno-obrazovne mjere, a manje na kažnjavanje..$^{51}$ Usvojeni sustav kažnjavanja i koncept maloljetničkog sudovanja pojedinih država ogleda se među ostalim faktorima i time koja je granična dob kaznene odgovornosti. Moguće su različite solucije određivanja minimalne dobi kaznene odgovornosti, ali je ipak najzastupljenije rješenje na temelju (apsolutno) određene dobne granice, tj. starosti djeteta. ${ }^{52}$ Neki sustavi dopuštaju i drukčiju konstrukciju kaznene odgovornosti

49 Vidi više u: Radić, op. cit. u bilj. 22; Dragičević Prtenjača; Bezić, op. cit. u bilj. 3; više o minimalnoj dobi i pitanjima maloljetničkog pravosuđa u SAD-u vidi u: Lipsey, M. W.; Howell, J. C.; Kelly, M. R.; Chapman, G.; Carver, D., Improving the Effectiveness of Juvenile Justice Programs: A New Perspective on Evidence-Based Practice, Center for Juvenile Justice Reform, Georgetown Public Policy Institute, Georgetown University, Washington, D.C., 2010.

50 Radić, op. cit. u bilj. 34, str. 97.

51 Dünkel, F., Juvenile Justice Systems in Europe, Reform Developments Between Justice, Welfare and "Mew Punitiveness", Kriminologijos studijos, br. 1, 2014., str. 43 - 45.

52 Primjerice, ako je osoba navršila 12 godina, bit će kazneno odgovorna. Tako je u Švicarskoj, Velikoj Britaniji (Engleska i Wales), Sjevernoj Irskoj i na Novom Zelandu minimalna dob kaznene odgovornosti 10 godina; u Belgiji, Nizozemskoj, Škotskoj, Turskoj i Kanadi minimalna je dob 12 godina; u Austriji, Italiji, Makedoniji, Njemačkoj, Španjolskoj i većini država istočne Europe minimalna je dob 14 godina. Više vidi na: https://www.niacro.co.uk/age-criminal-responsibility (7. kolovoza 2021.); za dob kaznene odgovornosti u Europi vidi: https://archive.crin.org/en/ home/ages/europe.html (1. kolovoza 2021.).

Posebna je situacija s minimalnom dobi kaznene odgovornosti u Sjedinjenim Američkim Državama (dalje u tekstu: SAD), u kojima je svaka država odredila svoju granicu, odnosno minimalnu dob kaznene odgovornosti. Dakle, u SAD-u ne postoji jedinstven i ujednačen pristup određivanju minimalne dobi kaznene odgovornosti iako se u većini država služe testom utvrđivanja sposobnosti za rasuđivanje kod djece. U nekim je državama određena minimalna dob kaznene dogovornosti, pa je tako u Sjevernoj Karolini ona određena na 7 godina, a najviša je postavljena na 10 godina u Wisconsinu. Više vidi na: https://archive.crin.org/en/home/ages/Americas.html (7. kolovoza 2021.) i na: https://www.hg.org/juvenile-crime-law.html (8. kolovoza 2021.). Više informacija o minimalnoj dobi kaznene odgovornosti u Americi (Južnoj Americi) dostupno je na: https://archive.crin.org/en/home/ages/Americas.html (7. kolovoza 2021.). O minimalnoj dobi kaznene odgovornosti na Novom Zelandu podaci su dostupni na: https://www.stuff.co.nz/national/crime/116585038/as-countries-look-to-raise-the-age-of-criminal-responsibility-should-nz-too (7. kolovoza 2021.). 
tzv. prijelaznim (kliznim) sustavom ${ }^{53}$ kada se kaznena odgovornost uspostavlja s obzirom na postignuti stupanj zrelosti djeteta, odnosno vaganjem njegove dobi i njegove zrelosti, tj. stupnjem razvijenosti njegove ličnosti (Francuska). ${ }^{54}$ Određene države (primjerice Irska i Litva) imaju prijelazni sustav, koji ovisi o težini počinjenog kaznenog djela ${ }^{55}$, a ne primarno o zrelosti počinitelja. Doduše, smatra se, tj. postoji pretpostavka, da dijete određene dobi shvaća što nije dopušteno činiti, odnosno shvaća zabranjenost djela. Zbog toga je kod težih kaznenih djela, ponajprije kod tzv. delicta per se (kaznena djela po sebi) ${ }^{56}$, u nekim državama propisana manja dob za uspostavljanje kaznene odgovornosti u odnosu na druga kaznena djela (primjerice u odnosu na tzv. delicta mere prohibita). ${ }^{57}$

53 Primjerice, minimalna dob kaznene odgovornosti je između 10. i 14. godine, ovisno o stupnju zrelosti.

54 Francuska ima usvojen princip tzv. discernementa (poseban oblik volje i sposobnosti za rasuđivanje). Više vidi u: Dragičević Prtenjača; Bezić, op. cit. u bilj. 3.

55 Primjerice, načelno će dijete biti kazneno odgovorno od 12 godina, ali ako je riječ o teškim kaznenim djelima, na primjer ubojstvu, onda može biti odgovorno već od 10 godina. Takav sustav ima Irska, u kojoj djeca u dobi od 10 do 11 godina mogu biti kazneno odgovorna za usmrćenja i ubojstva, dok će za druga kaznena djela biti odgovorna tek s 12 godina. Sličan sustav ima i Litva, u kojoj je minimalna dob kaznene odgovornosti za teža kaznena djela, primjerice usmrćenja i ubojstva, 14 godina, a za ostala kaznena djela 16 godina. Više vidi na: https://archive.crin.org/ en/home/ages/europe.html (7. kolovoza 2021.).

56 To su kaznena djela za koja se samo po sebi podrazumijeva da su kaznena djela. Više o tom pojmu vidi u: Novoselec, P., Opći dio kaznenog prava, Pravni fakultet, Osijek, 2016., str. 254. Primjerice, ubojstvo, teško ubojstvo i sl.

57 To su zabranjena ponašanja, kaznena djela kod kojih se protupravnost djela može spoznati samo poznavanjem određenih propisa. Više o tom pojmu vidi u: Novoselec, op. cit. u bilj. 56, str. 255. Tako je, primjerice, kao što je navedeno u Irskoj i Litvi. 


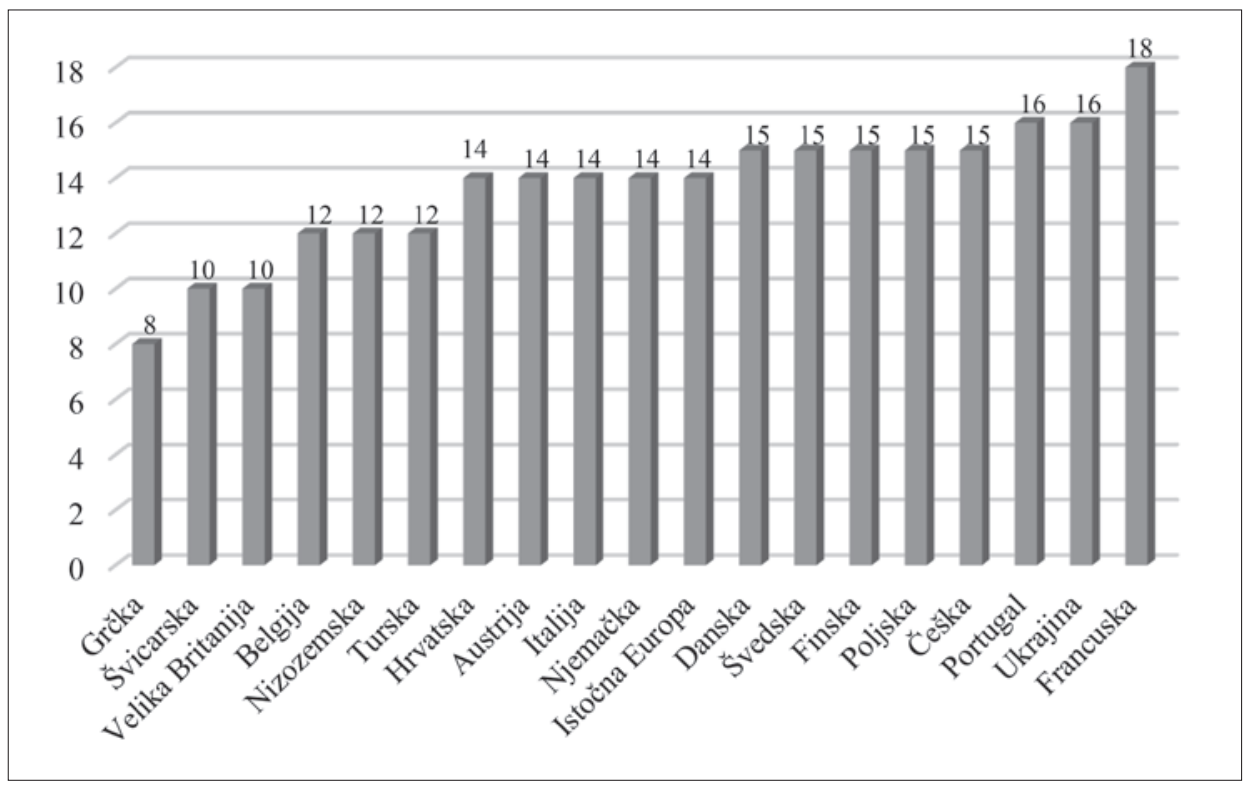

Graf 2: Minimalna dob kaznene odgovornosti u odabranim državama ${ }^{58}$

Prema Standardnim minimalnim pravilima UN-a, odnosno Pekinškim pravilima, minimalna dob kaznene odgovornosti ne smije biti preniska, nego se mora voditi računa o emocionalnoj, mentalnoj i intelektualnoj zrelosti djeteta. ${ }^{59}$ Dob je često ogledalo biopsiholoških osobina maloljetnika, koje su gotovo po

58 Više vidi na: https://archive.crin.org/en/home/ages/europe.html (7. lipnja 2020.). O minimalnoj dobi kaznene odgovornosti te maloljetničkim sankcijama u Nizozemskoj vidi na: https://www.government.nl/topics/sentences-and-non-punitive-orders/ penalties-juvenile-offenders (8. lipnja 2020.). Francuska ima usvojen sustav discernementa, odnosno doli capax, u kojem se utvrđuje stupanj zrelosti djeteta te se ovisno o tome konstruira i kaznena odgovornost. U potonjem sustavu, koji ima usvojen model odgovornosti baziran na discernementu, odnosno doli capax, mogu kazneno odgovarati i mlađa djeca ako su bila sposobna shvatiti značenje svojeg postupanja, tj. ako su bila svjesna da čine nešto zabranjeno, ali su sankcije koje se na njih imaju primijeniti drukčije od onih za odrasle počinitelje. Više o tim pojmovima vidi u: Rittossa; Božićević-Grbić, op. cit. u bilj. 10, str. 617; Dragičević Prtenjača; Bezić, op. cit. $u$ bilj. 3, str. 2, 3, 6, 7, 20.

Primjerice, u Grčkoj je minimalna dob kaznene odgovornosti određena na 8 godina, ali se mogu izreći samo blaže sankcije, odgojne i terapeutske mjere. To su kaznena djela za koja se podrazumijeva da su kaznena djela. Više o tom pojmu vidi u: Novoselec, op. cit. u bilj. 56, str. 254. Primjerice, ubojstvo, teško ubojstvo i sl.

59 Standardna minimalna pravila UN-a, A/RES/40/33; čl. 4., t. 4.1., str. 207, dostupna na: https://www.refworld.org/docid/3b00f2203c.html (10. lipnja 2020.). 
svemu (stupnju socijalne prilagođenosti, intelektualnom i emocionalnom razvoju) drukčije od osobina punoljetnih osoba, ali, dakako, drukčijim biopsihološkim osobinama doprinose i odgoj, sredina u kojoj odrastaju te emotivni razvoj i zrelost. ${ }^{60}$ Među ostalim se o pitanju minimalne dobi kaznene dogovornosti raspravljalo i pred Europskim sudom za ljudska prava (dalje u tekstu: ESLJP ili Sud) u predmetu $T .^{61} i \mathrm{~V}$. protiv Ujedinjenog Kraljevstva. ${ }^{62}$ Predmet je inače vrlo važan s aspekta maloljetničkog kaznenog prava jer su se njime načela brojna pitanja u vezi s raznim konvencijskim (Europske konvencije za zaštitu ljudskih prava i temeljnih sloboda (dalje u tekstu: EKLJP)) ${ }^{63}$ povredama (čl. 3., čl. 5. i čl. 6. EKLJP-a) ${ }^{64}$ kada su u pitanju djeca počinitelji kaznenih djela. Kao što je navedeno, među ostalim se našlo i pitanje predstavlja li izricanje kazne zatvora djeci u dobi od 10 do 14 godina ${ }^{65}$ povredu prema čl. 3. (zabrana mučenja) EKLJP-a, pri čemu se razmatralo i polemiziralo i o pitanju minimalne dobi za kaznenu odgovornost. Sud je zaključio kako nema povrede čl. 3. EKLJP-a u vezi s tim pitanjem i da određena dob od 10 godina kao minimalna dob kaznene odgovornosti nije prenisko određena. ${ }^{66}$

60 Zagorec, M., Maloljetnički zatvor u hrvatskom kaznenopravnom sustavu, doktorska disertacija, Pravni fakultet Sveučilišta u Zagrebu, Zagreb, 2019., str. 16; Bezić, R., Juvenile Delinquency in the Balkans: A Regional Comparative Analysis based on the ISRD3Study Findings, Max-Planck-Gesellschaft zur Förderung der Wissenschaften e.V. u suradnji s Duncker \& Humblot, Berlin, 2020., str. 92 - 106.

${ }_{61}$ Presuda ESLJP-a T. protiv Ujedinjenog Kraljevstva (T. v. United Kingdom), zahtjev br. 24724/94 od dana 16. prosinca 1999., § 18, 27; dostupna na: https://hudoc.echr. coe.int/eng\# \{\%22itemid\%22:[\%22001-58593\%22]\} i na https://hudoc.echr.coe.int/ eng\#\{\%22fulltext\%22:[\%22T.\%20and\%20V.\%20v.\%20United\%22],\%22documentcollectionid2\%22:[\%22GRANDCHAMBER\%22,\%22CHAMBER\%22],\%22itemid\%22:[\%22001-58593\%22]\} (10. lipnja 2020.).

62 Presuda ESLJP-a, V. protiv Ujedinjenog Kraljevstva (V. v. United Kingdom), zahtjev br. 24888/94 od dana 16. prosinca 1999., \$17, 19, 29; dostupna na: https://hudoc.echr. coe.int/eng\#\{\%22itemid\%22:[\%22001-58594\%22]\} (10. lipnja 2020.).

63 To je pitanje primarno bilo razmatrano u povodu pitanja pravilnosti tijekom suđenja. Više o tim slučajevima i pitanjima koja su se pojavila vidi na: https://archive. crin.org/en/library/legal-database/t-and-v-v-united-kingdom.html (10. lipnja 2020.). Taj je slučaj poznat i pod nazivom Bulger case (1993.).

64 Hrabar, D., Zaštita djece u kaznenom postupku u promišljanjima o pravosuđu naklonjenom djeci, Godišnjak Akademije pravnih znanosti Hrvatske, vol. IX, br. 1, 2018., str. 23.

$65 \mathrm{U}$ to vrijeme u Engleskoj je minimalna dob kaznene odgovornosti bila određena klizno, od 10 do 14 godina, ovisno o tzv. doli capax ili sposobnosti djeteta za rasuđivanje i shvaćanje značenja svojeg postupanja.

${ }^{66}$ Iako se u praksi ESLJP-a nije našao predmet koji bi se izravno odnosio na pitanje primjene maloljetničkog zatvora prema djeci maloljetnicima, naišlo se na niz pred- 


\section{2. ŠTO STOJI IZA ODLUKE SUDA O PRIMJENI MALOLJETNIČKOG ZATVORA ILI PRIDRŽAJA MALOLJETNIČKOG ZATVORA - ISTRAŽIVANJE O KRITERIJIMA RAZGRANIČENJA}

Istraživanjem se nastojalo razmotriti i uvidjeti postoje li određeni formalni kriteriji za razgraničenje primjene maloljetničkog zatvora od njegova pridržaja, odnosno kriteriji kojima se suci vode pri odlučivanju kada i u kojim slučajevima primijeniti maloljetnički zatvor, a kada njegov pridržaj. Sukladno tome u radu je postavljena i hipoteza $(\mathrm{H})$ : Postoje kriteriji za razgraničenje primjene maloljetničkog zatvora od pridržaja maloljetničkog zatvora. Istraživanje će se provesti koristeći se normativno-deskriptivnom analizom (odredaba ZSM-a i KZ-a), kvalitativnom analizom pet presuda Županijskog suda u Zagrebu te deskriptivnom analizom podataka Državnog zavoda za statistiku.

meta u kojima se raspravljalo o raznim drugim povredama konvencijskih prava maloljetnika koji su počinili kaznena djela. Tako je našao povredu čl. 6. EKLJP-a u predmetu Adamkiewicz protiv Poljske (zahtjev br. 54729/00) od dana 2. ožujka 2010. (konačna 4. 10. 2010.); dostupna na: https://hudoc.echr.coe.int/eng\#\{\%22itemid\%22:[\%22001-97477\%22]\} (20. kolovoza 2020.) kao i u predmetu Panovits v. Cyprus, (zahtjev br. 4268/04) od dana 11. prosinca 2008. (konačna 11. 3. 2009.) te u predmetu Salduz protiv Turske, Presuda ESLJP-a Salduz protiv Turske (zahtjev br. 36391/02) od dana 27. studenog 2008. Više vidi u: Ivičević Karas, E., Pomicanje granica prava na branitelja pod utjecajem europskog kaznenog prava, Hrvatski ljetopis za kazneno pravo i praksu, vol. 22, br. 2, 2015., str. 359. U predmetu Blokhin protiv Rusije ESLJP je našao povredu čl. 3., čl. 5. i čl. 6. (st. 1. i 3.). Presuda ESLJP-a Blokhin protiv Rusije (zahtjev br. 47152/06) od dana 23. ožujka 2016.; dostupna na: https://hudoc.echr.coe.int/ eng\#\{\%22fulltext\%22:[\%22Blokhin\%22],\%22itemid\%22:[\%22001-161822\%22]\} (20. kolovoza 2020.). Posebno je zanimljiv predmet Çoşelav protiv Turske, koji u velikoj mjeri podsjeća na događaj s tragičnim epilogom u Hrvatskoj, kada je u istražnom zatvoru smrtno stradao mlađi punoljetnik s mentalnim i tjelesnim teškoćama i dijagnozom ADHD-a koji si je oduzeo život. Presuda ESLJP-a Çoşelav protiv Turske (zahtjev br. 1413/07) od dana 9. 10. 2010. (konačna 18. 3. 2013.); dostupna na: https://hudoc.echr.coe.int/eng\# \{\%22fulltext\%22:[\%22\%C3\%87O\%C5\%9EELAV\%20v.\%20TURKEY\%22],\%22documentcollectionid2\%22:[\%22GRANDCHAMBER\%22,\%22CHAMBER\%22],\%22itemid\%22:[\%22001-113767\%22]\} (19. srpnja 2021.). Više vidi u: Marić Banje, K., Tko je odgovoran? Novi detalji o smrti mladića koji je s teškim ozljedama prebačen iz zatvora u splitski KBC gdje je umro - Oglasili se DORH i Ministarstvo pravosuda; Jutarnji list, 27. kolovoza 2019.; dostupno na: https:// www.jutarnji.hr/vijesti/hrvatska/novi-detalji-o-smrti-mladica-koji-je-s-teskim-ozljedama-prebacen-iz-zatvora-u-splitski-kbc-gdje-je-umro-oglasili-se-dorh-i-ministarstvo-pravosuda-9286304 (20. srpnja 2021.). Kasnijom provjerom utvrđen je niz propusta u postupanju nadležnih tijela, ali i nedostaci u sustavu. Detalje o slučaju vidi u: Zagorec, op. cit. u bilj. 60, str. 140 - 142; Zagorec, op. cit. u bilj. 32, str. 283 - 301. 


\subsection{Normativno-deskriptivna analiza: uvjeti za izricanje maloljetničkog zatvora odnosno njegova pridržaja}

Maloljetnički zatvor najstroža je među maloljetničkim sankcijama koja se može izreći isključivo starijim maloljetnicima (16 - 18). Uz to temeljno ograničenje, odlikuju ga i još neke posebnosti. ${ }^{67}$ Primjerice, može se izreći u točno propisanom trajanju ${ }^{68}$ i za određena 'teža' kaznena djela ${ }^{69}$ te sud mora biti uvjeren da je takva kazna potrebna. ${ }^{70}$ Time se potvrđuje i načelo razmjernosti, tj. da kazna mora biti razmjerna stupnju krivnje i svrsi kažnjavanja (koja je specifična za maloljetnike), ali i načelo supsidijariteta da se maloljetniku neće izreći teža sankcija ako se ista svrha može postići blažom sankcijom..$^{71}$ Ako se sud ipak odluči na izricanje maloljetničkog zatvora, što iz prakse proizlazi da je iznimno rijetko, na maloljetnika se primjenjuje niz prava koja su zajamčena odredbama već spomenutih zakona ${ }^{72}$, ali i zakona i propisa kojima se regulira izvršavanje kazne zatvora. ${ }^{73}$

67 Uvjeti izricanja, trajanje, svrha i sadržaj sankcije (čl. 24. ZSM-a).

68 Ne može biti kraći od šest mjeseci ni dulji od pet godina, a izriče se na pune godine i mjesece (čl. 25. st. 1. ZSM-a). Bitno je napomenuti ako je za određeno kazneno djelo propisana kazna zatvora, kao u primjeru počinjenja tjelesne ozljede prema bliskoj osobi, u trajanju od jedne do tri godine, tada sud može izreći i manju kaznu od jedne godine, primjerice, može mu izreći kaznu maloljetničkog zatvora od šest mjeseci (koja je propisana kao opći minimum za kaznu maloljetničkog zatvora), ali se ne može izreći u trajanju duljem od propisanog posebnog maksimuma, odnosno dulje od tri godine (čl. 25. st. 2. ZSM-a).

${ }_{69}$ Za koja je u zakonu propisana kazna zatvora tri godine ili teža, i to samo kada sud to ocijeni potrebnim, odnosno kada s obzirom na "narav i težinu djela te visoki stupanj krivnje ne bi bilo opravdano izreći odgojnu mjeru, već je potrebno kažnjavanje" (čl. 24. st. 2. ZSM-a). Dotičnu odredbu ima se razumjeti tako da se maloljetnički zatvor može izreći i za ona kaznena djela za koja se može izreći kazna od tri godine, primjerice kazna za kazneno djelo tjelesne ozljede počinjene prema bliskoj osobi (čl. 117. st. 2. KZ-a), za koju je propisana kazna zatvora od jedne do tri godine, ali se ne bi mogao izreći za temeljni oblik tog kaznenog djela (čl. 117. st. 1 . KZ-a), za koji je propisana kazna zatvora do jedne godine.

70 Ricijaš, N., Obilježja maloljetnika koji izvršavaju kaznu maloljetničkog zatvora u Republici Hrvatskoj, Kriminologija i socijalna integracija, vol. 13, br. 1, 2005., str. 90, str. 89 - 105. Više vidi u: Hirjan, F.; Singer, M., Komentar Zakona o sudovima za mladež i kaznenih djela na štetu djece i maloljetnika, MUP RH, Zagreb, 1998.

71 Više o tom pojmu vidi u: Derenčinović, D.; Getoš, A.-M., Uvod u kriminologiju s osnovama kaznenog prava, Pravni fakultet Sveučilišta u Zagrebu, Zagreb, 2008., str. 265.

72 Čl. 101. ZSM-a i Ricijaš, op. cit. u bilj. 70, str. 89.

73 Vidi odredbe čl. 53. - 57. Zakona o izvršavanju sankcija izrečenih maloljetnicima za kaznena djela i prekršaje, Narodne novine, br. 133/2012, Pravilnik o načinu izvr- 
Međutim, koji su to kriteriji koji bi trebali biti odlučujući pri formiranju stava i odluke suda o potrebnosti izricanja baš određene sankcije (kazne) u ZSM-u nije navedeno, nego je cjelokupna odluka prepuštena diskrecijskoj ocjeni suda i suca. Na problematiku (ne)postojanja jasnih i decidiranih kriterija upozorila je i Cvjetko. ${ }^{74}$ Ako ne postoje formalni kriteriji, a u ZSM-u se ne nalaze, proizlazi kako sud ima diskrecijsko pravo odlučiti kada će izreći maloljetnički zatvor, a kada primijeniti njegov pridržaj. ${ }^{75}$ Sud se može odlučiti za pridržaj kada smatra da bi se samo utvrđivanjem krivnje maloljetnika bez izricanja kazne zatvora, ali i pod prijetnjom njegova naknadnog izricanja, moglo odvratiti maloljetnika od činjenja daljnjih kaznenih djela. ${ }^{76}$ Potrebno je napomenuti kako je pridržaj maloljetničkog zatvora pandan uvjetnoj osudi iz KZ-a ${ }^{77}$ koja se izriče, tj. primjenjuje na punoljetne (odrasle) počinitelje kaznenih djela, a za koju su jasno propisani formalni kriteriji njezina izricanja. ${ }^{78} \mathrm{U}$ situaciji pridržaja maloljetničkog zatvora sud izriče da je maloljetnik kriv za počinjeno kazneno djelo, ne izričući mu kaznu kao kod uvjetne osude, nego samo pridržava izricanje maloljetničkog zatvora. Materijalni razlozi za pridržaj su propisani, ali dosta općenito. ${ }^{79}$ Formalnog kriterija u ZSM-u nema. Dakle, pridržaj se može izreći za bilo koje kazneno djelo, pa čak i za ona teža i vrlo ozbiljna kaznena djela. Doduše, sud može maloljetnika obvezati da se uz pridržaj pridržava i nekih odgojnih mjera ${ }^{80}$ koje mu može izreći, kao i određene sigurnosne mjere. ${ }^{81}$ Vrijeme provjeravanja

šavanja kazne maloljetničkog zatvora u kaznenom i prekršajnom postupku, Narodne novine, br. 57/2013; podredno Zakon o izvršavanju kazne zatvora, Narodne novine, br. 14/2021 te eventualno i pripadajući kućni red kaznionice odnosno zatvora (čl. 2. Pravilnika o načinu izvršavanja kazne maloljetničkog zatvora u kaznenom i prekršajnom postupku).

74 Cvjetko, B., Zakonska i sudska politika kažnjavanja maloljetnika i mlađih punoljetnika kaznom maloljetničkog zatvora (1998. - 2003.), Hrvatski ljetopis za kazneno pravo i praksu, vol. 11, broj 2, 2004., str. 842 .

75 Čl. 28. ZSM-a.

76 Ibid.

77 Čl. 56. KZ-a.

78 Može se izreći ako je počinitelj osuđen na kaznu zatvora do jedne godine ili novčanu kaznu (čl. 56. st. 2. KZ-a).

Čl. 28. st. 1. ZSM-a.

Sud može izreći i odgojne mjere pojačanog nadzora, upućivanje u disciplinski centar te jednu ili više posebnih obveza koje maksimalno mogu trajati do isteka vremena provjeravanja (čl. 28. st. 1. ZSM-a).

81 Sud može postaviti i uvjet da se podvrgne izrečenoj sigurnosnoj mjeri obveznog psihijatrijskog liječenja ili obveznog liječenja od ovisnosti ili zabrani upravljanja motornim vozilom (čl. 28. st. 3. ZSM-a). 
kod pridržaja je od jedne do tri godine. ${ }^{82}$ Dakle, čak ako je maloljetnik počinio, primjerice, kazneno djelo razbojništva ${ }^{83}$ ili teškog ubojstva ${ }^{84}$ ili čak stjecaj više ozbiljnih kaznenih djela, sud se može odlučiti da će mu izreći pridržaj maloljetničkog zatvora jer ne postoji nikakvo formalno ograničenje. ${ }^{85}$

Važno je istaknuti da se prilikom odmjeravanja kazne maloljetniku sud ima voditi pravilima za odmjeravanje propisanim u KZ-u ${ }^{86}$, ali mora i posebno voditi računa o stupnju zrelosti maloljetnika, vremenu koje je potrebno za njegov odgoj, obrazovanje i stručno osposobljavanje. ${ }^{87}$

\subsection{Kvalitativno i deskriptivno istraživanje}

Slijedeći istraživanje koje je provela Zagorec ${ }^{88}$, naišlo se na određene zanimljivosti koje su pobudile interes autorica za daljnjim razmatranjem navedenog

82 Ne može biti kraće od jedne ni duže od tri godine (čl. 28. st. 2. ZSM-a); kod uvjetne osude je $1-5$ (čl. 56. st. 3. KZ-a).

83 Za čiji temeljni oblik je propisana kazna zatvora od 1 do 10 godina (čl. 230. st. 1 . KZ-a).

84 Za koje je propisana kazna zatvora od najmanje 10 godina (dakle do 20 god.) ili kazna dugotrajnog zatvora (21 - 40 godina) (čl. 111. KZ-a).

85 Kada su počinjena teška kaznena djela za koja je, primjerice, propisana kazna dugotrajnog zatvora, navedeno je u ZSM-u da sud može (ako to hoće, ako se tako odluči, op. a.) izreći kaznu maloljetničkog zatvora u trajanju do 10 godina (čl. 25. st. 1. ZSM-a), a ne da mora. Dakle, ne mora se odlučiti za tu soluciju, pa može i pridržaj maloljetničkoga zatvora. Potrebno je upozoriti na to kako je jednako velika i diskrecijska ocjena suda, bez jasno definiranih kriterija, i kada odlučuje hoće li mu naknadno izreći kaznu maloljetničkog zatvora ili neće. Čl. 29. ZSM-a.

86 Čl. 47. KZ-a. Inače se pri izboru vrste i (mjere) kazne tijekom odmjeravanja sud mora voditi generički nabrojenim subjektivnim i objektivnim okolnostima (Horvatić, Ž.; Derenčinović, D.; Cvitanović, L., Kazneno pravo opći dio 2 - Kazneno djelo i kaznenopravne sankcije, Pravni fakultet Sveučilišta u Zagrebu, Zagreb, 2017., str. 241 - 251) posebno imajući u vidu stupanj krivnje i svrhu kažnjavanja. Te okolnosti bile bi jačina ugrožavanja ili povrede zaštićenog dobra, pobude iz kojih je kazneno djelo počinjeno, stupanj povrede počiniteljevih dužnosti, način počinjenja i skrivljeni učinci kaznenog djela, prijašnji počiniteljev život, njegove osobne i imovinske prilike te njegovo ponašanje nakon počinjenog kaznenog djela, odnos prema žrtvi i trud da naknadi štetu (st. 1.), s naglaskom da visina kazne ne smije prekoračiti stupanj krivnje (st. 2.).

87 Čl. 25. st. 3. ZSM-a. Više o razmjernosti sankcija, odnosno njihovu odvraćajućem učinku s obzirom na ličnost počinitelja, vidi u: Beccaria, C., On Crimes and Punishments and Other Writings, University of Toronto Press, Toronto, 2008., str. 17 i 49.

88 Zagorec je provela istraživanje koristeći se prigodnim uzorkom, uzevši u obzir sve pravomoćno okončane predmete za kazneno djelo razbojništva, koji su dovršeni u 
pitanja. Zagorec je $\mathrm{u}$ istraživanju, među ostalim, provela kvalitativnu analizu pet presuda Županijskog suda u Zagrebu (dalje u tekstu: ŽSZg) s jednim ili više okrivljenika u kojima su maloljetnicima i mlađim punoljetnicima bili izrečeni maloljetnički zatvor ili njegov pridržaj za jedno od težih kaznenih djela - kazneno djelo razbojništva. Taj je nalaz, upravo zato što je riječ o jednom te istom kaznenom djelu, zaintrigirao autorice namećući pitanje postoje li neki kriteriji kojima se suci vode u takvim slučajevima pri odlučivanju kada primijeniti jednu od tih dviju sankcija (maloljetnički zatvor odnosno pridržaj maloljetničkog zatvora) ili je sve prepušteno na volju sudaca, odnosno njihovoj diskrecijskoj odluci, što je utjecalo i na formiranje hipoteze.

Tablica 1 sumira rezultate istraživanja koje je provela Zagorec, i to kvalitativnom analizom pet presuda Županijskog suda u Zagrebu s više okrivljenika za kazneno djelo razbojništva. ${ }^{89}$ Ona je nakon provedenog istraživanja uočila naznačeni problem i postavila pitanje o tome postoje li jasni kriteriji u praksi prilikom odmjeravanja maloljetničkog zatvora, odnosno pridržaja maloljetničkog zatvora, no bez daljnje razrade. Stoga smo odlučile postaviti hipotezu i provjeriti je promatranjem pojedinih varijabli te zaključiti postoje li kakvi kriteriji i, ako postoje, koji su od njih prevalentni za odlučivanje.

Primjerice, iz prikazanih podataka proizlazi kako sud nije izrekao maloljetnički zatvor ni jednom (starijem) maloljetniku, nego im je u pravilu izrečen pridržaj i/ili sigurnosna mjera, dok je u većini slučajeva mlađim punoljetnicima bio izrican maloljetnički zatvor. Pitanje je stoga je li dob u vrijeme počinjenja djela odlučujući faktor. Međutim, slučaj mlađeg punoljetnika starog 18 - 19 godina (trećeg okrivljenika iz prvog slučaja), koji je već ranije bio osuđivan, dolazi iz disfunkcionalne obitelji i problematičnog je ponašanja i kojemu nije izrečen maloljetnički zatvor nego njegov pridržaj - opovrgava takav zaključak. $\mathrm{S}$ druge strane, okrivljenicima, isto mlađim punoljetnicima, u dobi od 18 godina, za isto je kazneno djelo (iz petog slučaja), koji su također recidivisti, dolaze iz disfunkcionalnih obitelji, problematičnog su ponašanja te su čak i priznali kazneno djelo - izrečen maloljetnički zatvor.

razdoblju od 2012. do 2019. na Županijskom sudu u Zagrebu. Zagorec, op. cit. u bilj. 60 , str. $191-214$.

89 Zagorec je provela kvalitativno istraživanje, a autorice rada su iz kvalitativnog istraživanja izvukle varijable kojima su se vodili suci pri odlučivanju (prikazani u Tablici 1) i nastojale ih prikazati u kvantitativnom obliku gdje da ili ne zamjenjuje 1 ili 0 . 
Tablica I: Prikaz rezultata kvalitativne analize pet presuda Županijskog suda u Zagrebu za kazneno djelo razbojništva (čl. 230. KZ-a) $)^{90}$

\begin{tabular}{|c|c|c|c|c|c|c|c|c|c|c|c|}
\hline 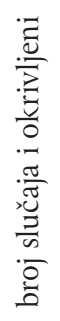 & 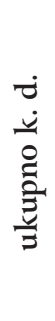 & 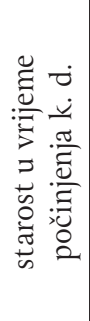 & 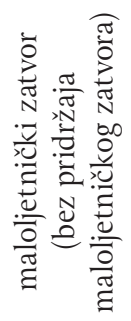 & 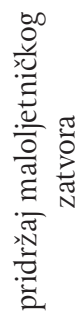 & 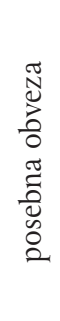 & 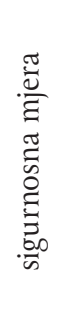 & 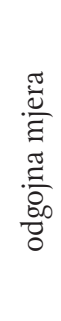 & 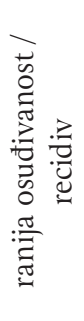 & 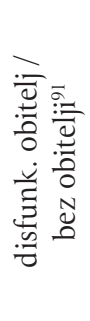 & 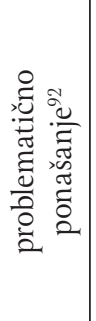 & 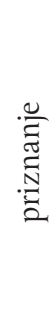 \\
\hline $1 / 1$ & 1 & $16 / 17$ & ne & da & $\mathrm{da}$ & ne & $\mathrm{da}$ & da & da & $\mathrm{da}$ & $?$ \\
\hline $1 / 2$ & 1 & $16 / 17$ & ne & da & $\mathrm{da}$ & ne & $\mathrm{da}$ & ne & da & $\mathrm{da}$ & $?$ \\
\hline $1 / 3$ & 2 & $18 / 19$ & ne & da & $\mathrm{da}$ & ne & $\mathrm{da}$ & da & $\mathrm{da}$ & $\mathrm{da}$ & $?$ \\
\hline $2 / 1$ & 1 & 18 & ne & $\mathrm{da}$ & $\mathrm{da}$ & ne & $\mathrm{da}$ & ne & ne & ne & $\mathrm{da}$ \\
\hline $2 / 2$ & 1 & 17 & ne & ne & $\mathrm{da}$ & ne & $\mathrm{da}$ & ne & ne & ne & da \\
\hline $2 / 3$ & 1 & 17 & ne & ne & $\mathrm{da}$ & ne & $\mathrm{da}$ & ne & ne & ne & da \\
\hline $3 / 1$ & 13 & 19 & da & ne & ne & $\mathrm{da}$ & ne & da & da & da & $?$ \\
\hline $4 / 1$ & 1 & 20 & da & ne & ne & ne & $\mathrm{da}$ & ne & $\mathrm{da}$ & ne & da \\
\hline $4 / 2$ & 1 & 19 & da & ne & ne & ne & $\mathrm{da}$ & ne & da & $\mathrm{da}$ & da \\
\hline $5 / 1$ & 1 & 18 & $\mathrm{da}$ & ne & ne & ne & ne & da & $\mathrm{da}$ & $\mathrm{da}$ & $\mathrm{da}$ \\
\hline $5 / 2$ & 1 & 18 & $\mathrm{da}$ & ne & ne & ne & ne & da & $\mathrm{da}$ & da & da \\
\hline
\end{tabular}

90 Ibid. Ovo su varijable koje se nalaze u obrazloženjima presuda (ŽSZg br.-4KMP-20/11 od 6. 3. 2012., ŽSZg br.-1-KMP-3/13 od 11. 3. 2014., ŽSZg br.-1KMP-9/14 od 28. 9. 2015., VSRH br. KŽM-37/15 od 21. 1. 2016., ŽSZg br. KMP1/16 od 21. 4. 2016., VSRH br. KŽM-25/16 od 11. 10. 2016., ŽSZg br.-1-KMP-1/17 od 20. 4. 2017.) i na temelju kojih su izricane sankcije. Svi počinitelji muškog su spola.

91 Varijabla disfunkcionalna obitelj je tako navedena u presudama bez dodatnih daljnjih objašnjenja (kao npr. nije navedeno je li riječ o cjelovitoj obitelji s disfunkcionalnim elementima ili je riječ o zlostavljanju, alkoholu...), a vrlo vjerojatno tu varijablu procjenjuju i definiraju u konkretnom slučaju stručni suradnici pri Državnom odvjetništvu te na sudu, kao i CZSS.

92 Varijabla problematično ponašanje je tako navedena u obrazloženju presuda bez dodatnih daljnjih obrazloženja o tome što se sve podrazumijeva pod tim pojmom (je li riječ o remećenju javnog reda i mira, neposluh ili loše vladanje u školi ili bavljenje kriminalom, odnosno o kojoj vrsti delinkventnog ponašanja je riječ i je li uopće riječ o delinkventnom ponašanju). 
Izgleda kako varijabla obiteljskih prilika (disfunkcionalna obitelj / bez obitelji) prema rezultatima istraživanja ima određeni utjecaj na izricanje maloljetničkog zatvora. Sud je u pravilu izricao maloljetnički zatvor mlađim punoljetnicima koji su, među ostalim, dolazili iz disfunkcionalnih obitelji.

Promatrajući faktor recidiva proizlazi kako se ne može ništa zaključiti o utjecaju te varijable na odlučivanje pri odabiru između dviju spomenutih sankcija jer iz podataka ne proizlazi jasno stajalište suda kako se vrednuje ta okolnost. Sud je u nekim slučajevima recidiva izricao maloljetnički zatvor, dok je u drugima izricao pridržaj.

Dobiveni podaci upućuju na činjenicu da trenutačno nije jasno koje su varijable prevalentne za odlučivanje kada izreći maloljetnički zatvor, a kada primijeniti njegov pridržaj te kako ne postoje jasni formalni kriteriji ni u sudskoj praksi ${ }^{93}$ Stoga se može reći kako iz Tablice l proizlazi da se sa sigurnošću, bez dodatnog daljnjeg istraživanja, ne može zaključiti da bilo koja od navedenih varijabli ima odlučujući učinak pri odabiru sankcije, a ne može se ništa zaključiti ni promatrajući kombinacije varijabli. Slijedom navedenog, ističe se da bi se za znanstveno značajnu provjeru navedene teze trebalo provesti dodatno kvalitativno (npr. kroz intervju sa sucima), ali i kvantitativno istraživanje kojim bi bilo obuhvaćeno dulje razdoblje (npr. u posljednjih 15 -ak godina ${ }^{94}$ ) i veći broj slučajeva ukupno osuđenih maloljetnika. Takvo istraživanje, međutim, prelazi okvire ovoga rada.

Autorice su upravo zbog iznesenog problema, malog broja slučajeva do kojih se došlo istraživanjem, odlučile konzultirati i podatke Državnog zavoda za statistiku za razdoblje od posljednjih deset godina (2010. - 2020.). ${ }^{95}$ Međutim, zbog iznimno malog broja osuđenih maloljetnika na kaznu maloljetničkog zatvora nije moguće provesti inferencijalnu statističku obradu podataka kojom bi se na razini statističke značajnosti moglo zaključiti o utjecaju kriterija (gore promatranih varijabli pojedinačno ili u kombinaciji) pri odlučivanju o sankcijama. Upravo zbog malog uzorka na razini cijele Hrvatske autorice su se odlučile provesti

93 Autorice su nastojale izdvojiti sve varijable (okolnosti) relevantne za odmjeravanje sankcije (maloljetnički zatvor i pridržaj maloljetničkog zatvora) iz (dostupnih) pravomoćnih presuda Županijskog suda u Zagrebu koje su pravomoćno okončane u razdoblju od 2012. do 2019., odnosno iz istraživanja koje je provela jedna od autorica rada u sklopu svoje doktorske disertacije.

$94 \mathrm{U}$ obzir bi trebalo uzeti minimalno razdoblje od 15 godina zbog malog broja osoba kojima je izrečena kazna maloljetničkog zatvora kako bismo dobile dovoljno velik uzorak za inferencijalnu statističku obradu podataka.

95 Državni zavod za statistiku, Baza podataka, dostupno na: https://www.dzs.hr (8. kolovoza 2021.). 
deskriptivnu analizu podataka, promatrajući izrečene sankcije maloljetničkog zatvora i njegova pridržaja u posljednjih deset godina (2010. - 2020.).

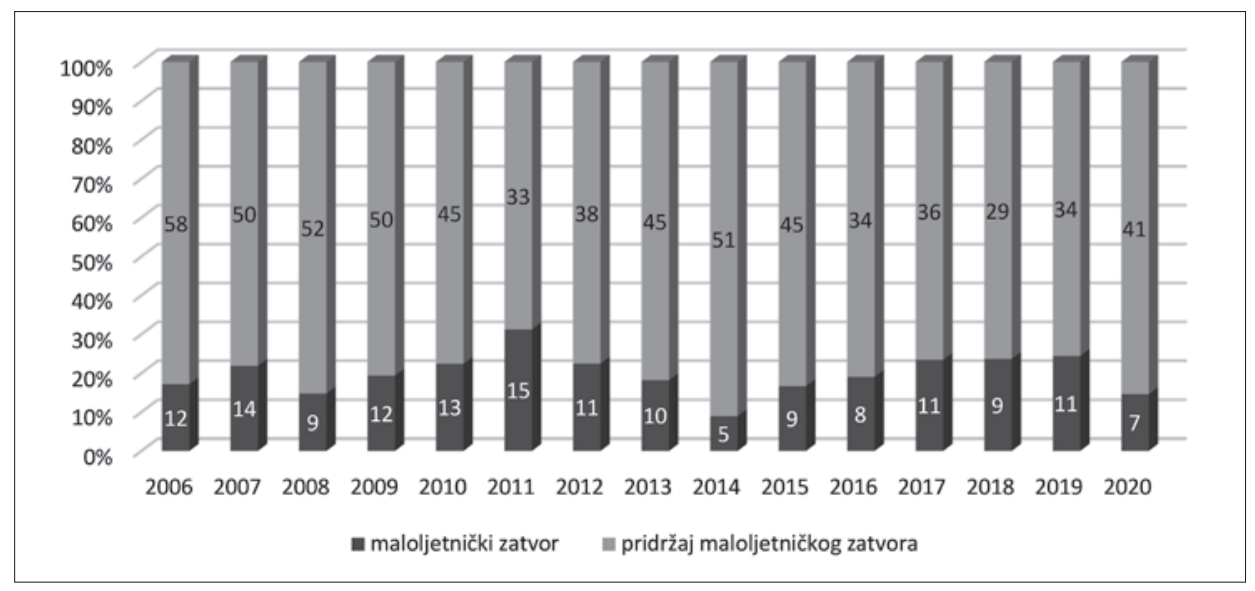

Graf 3: Prikaz broja osuđenih maloljetnika na sankciju maloljetničkog zatvora i pridržaja maloljetničkog zatvora u RH (2006. - 2020.)

Graf 3 prikazuje iznimno mali broj maloljetnika osuđenih na sankciju maloljetničkog zatvora u svim promatranim godinama (prosječna vrijednost je 10,4 godišnje). Iz prikazanih podataka u grafu 3 proizlazi da od ukupnog broja osuđenih maloljetnika na maloljetnički zatvor i pridržaj maloljetničkog zatvora najmanji je udio maloljetničkog zatvora bio 2014. i 2020. Možda je razlog takvim rezultatima u 2014. što je 2013. bila reforma kaznenog materijalnog prava, kada je na snagu stupio novi Kazneni zakon" ${ }^{96}$, pa je došlo do promjene kvalifikacija određenih ponašanja, a neka su prebačena u sferu prekršaja (primjerice, neki delikti vezani uz droge prešli su u prekršajnu sferu). Međutim, sličan rezultat zamijećen je i 2020. godine. Koji su uzroci tome, može se samo nagađati, ali je potrebno imati na umu kako je to bila pandemijska godina (Covid-19). Vrlo vjerojatno je razlog takvom stanju niz faktora koji se trenutačno ne mogu provjeriti, nego samo pretpostaviti i ostaviti za neka daljnja istraživanja. ${ }^{97}$ Zanimljivo je primijetiti kako je najveći postotak maloljetničkog zatvora (33\% od ukupnog broja maloljetnika kojima je izrečen maloljetnički zatvor i pridržaj maloljetnič-

96 Kazneni zakon, Narodne novine, br. 125/2011.

97 U vezi s pokazateljima u 2020. godini, prema neformalnim spoznajama autorica $u$ razgovorima sa sucima koji sude u maloljetničkim predmetima, stručnim suradnicima i državnim odvjetnicima češće se izricao pridržaj maloljetničkog zatvora nego maloljetnički zatvor zbog održavanja protupandemijskih mjera. 
kog zatvora) bio 2011. godine. Opet, ne može se sa sigurnošću tvrditi o čemu je riječ, ali je potrebno istaknuti kako je te godine bio donesen novi $\mathrm{ZSM}^{98}$, pa je moguće da se politika kažnjavanja sudova nešto promijenila.

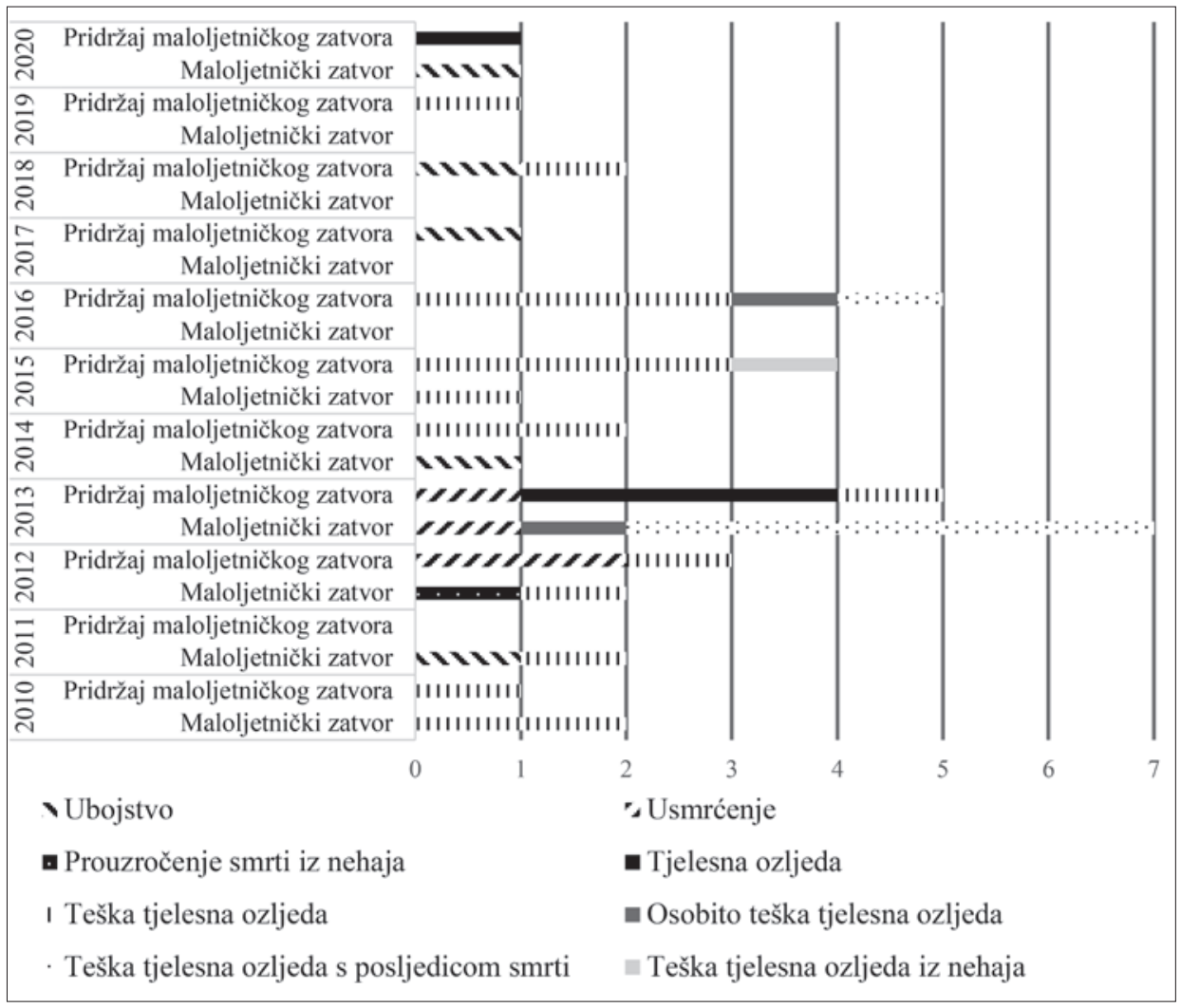

Graf 4: Prikaz broja osuđenih maloljetnika na sankciju maloljetničkog zatvora i pridržaja maloljetničkog zatvora u RH za kaznena djela protiv života i tijela (2010. - 2020.)

Graf 4 prikazuje ukupan broj maloljetnika u pojedinoj godini kojima je izrečen maloljetnički zatvor i pridržaj maloljetničkog zatvora za kaznena djela unutar glave protiv života i tijela. ${ }^{99}$ Za kazneno djelo ubojstva (čl. 110. KZ-a)

98 Zakon o sudovima za mladež, Narodne novine, br. 84/2011.

99 U grafu 4 nisu navedena sva kaznena djela unutar glave protiv života i tijela jer za njih u promatranom razdoblju nema maloljetnika kojima je izrečena sankcija maloljetničkog zatvora ili pridržaja maloljetničkog zatvora. 
u promatranom je razdoblju (2010. - 2020. $)^{100}$ bila izrečena sankcija pridržaja maloljetničkog zatvora 2017. i 2018. godine, dok je 2011., 2014. i 2020. bio izrečen maloljetnički zatvor. Napominje se kako je u razdoblju 2016. - 2020. maloljetnički zatvor izrečen jedino za kazneno djelo ubojstva i nijedno drugo kazneno djelo unutar promatrane glave, dok je u razdoblju od 2010. do 2015. bio izrečen i za tešku tjelesnu ozljedu (čl. 118. KZ-a), osobito tešku tjelesnu ozljedu (čl. 119. KZ-a), tjelesnu ozljedu s posljedicom smrti (čl. 120. KZ-a), prouzročenje smrti iz nehaja (čl.113. KZ-a) i usmrćenja (čl. 112. KZ-a). Promatramo li navedeno razdoblje (2010. - 2020.), proizlazi kako je za ista kaznena djela nekad izrečen maloljetnički zatvor, a nekad pridržaj. Svakako treba naglasiti da iz podataka DZS-a nema dostupnih informacija o okolnostima počinjenja pojedinog kaznenog djela, što bi bilo od važnosti uzeti u razmatranje u nekom budućem istraživanju.

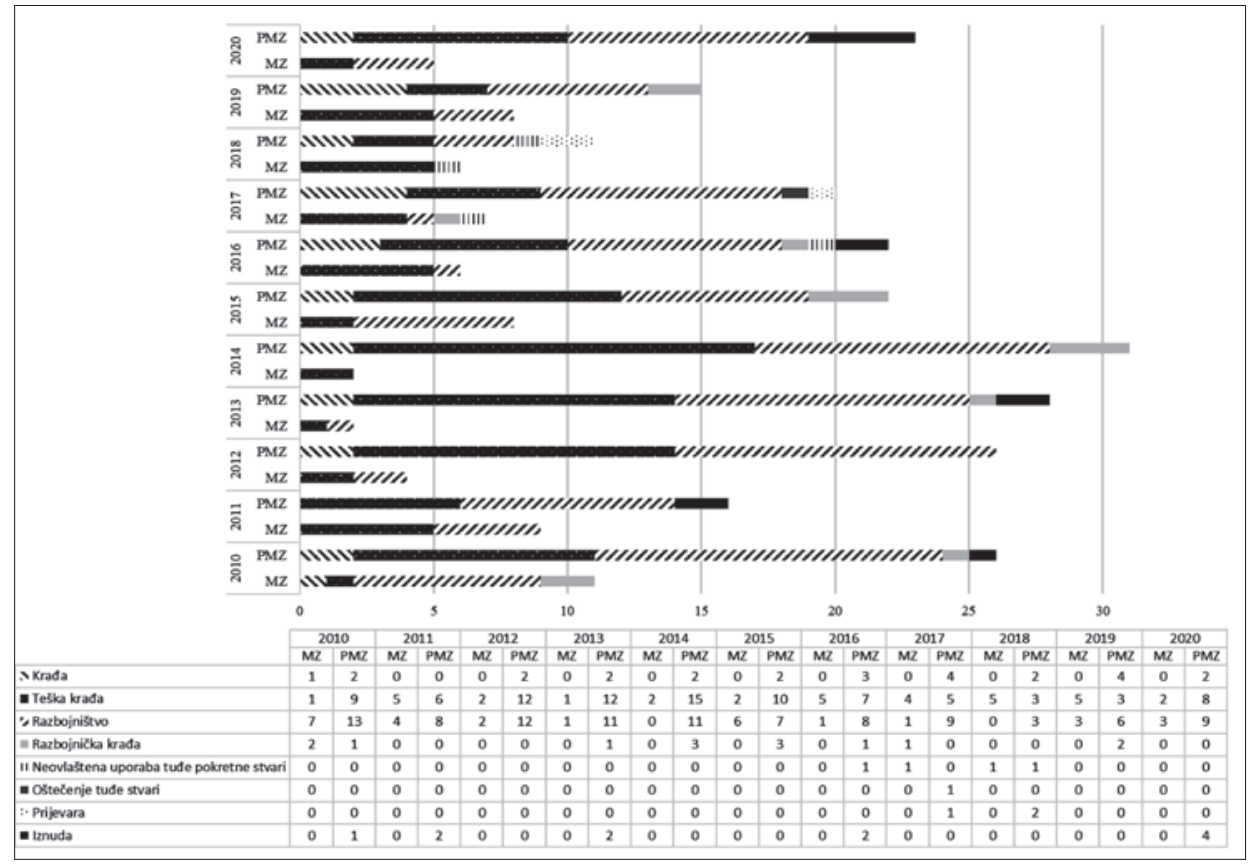

Graf 5: Prikaz broja osuđenih maloljetnika na sankciju maloljetničkog zatvora (MZ) i pridržaja maloljetničkog zatvora (PMZ) u RH za kaznena djela protiv imovine (2010. - 2020.)

${ }^{100}$ Graf 4 prikazuje razdoblje od deset godina kako bi se na što dužem razdoblju vidjelo kretanje sankcija maloljetničkog zatvora i pridržaja maloljetničkog zatvora za kaznena djela unutar glave protiv života i tijela. 
Graf 5 prikazuje ukupan broj maloljetnika kojima je izrečena sankcija maloljetničkog zatvora i pridržaja maloljetničkog zatvora za kaznena djela protiv imovine u razdoblju od 2010. do 2020. godine. Kaznena djela protiv imovine odabrana su jer maloljetnici čine najčešće upravo ta kaznena djela i ona su općenito najzastupljenija u strukturi općeg kriminala. ${ }^{101}$

Zanimljivo je da se kazna maloljetničkog zatvora u promatranom razdoblju (2010. - 2020.) najčešće izricala za kazneno djelo teške krađe (čl. 229. KZ-a), dok se pridržaj maloljetničkog zatvora najčešće izricao za razbojništvo (čl. 230. KZ-a) i tešku krađu (čl. 229. KZ-a). To je zanimljivo s aspekta određenih okolnosti, primjerice nasilja pri počinjenju kaznenog djela, jer razbojništvo podrazumijeva primjenu sile ili prijetnje pri ostvarenju bića djela.

Kod kaznenih djela krađe (čl. 228. KZ-a) te razbojničke krađe (čl. 231. KZ-a) u promatranom razdoblju je u gotovo u svim slučajevima izrečen pridržaj maloljetničkog zatvora, uz iznimku 2010. godine, kada je izrečen maloljetnički zatvor, što u pravilu upućuje na ujednačenu distribuciju. Kod kaznenih djela teške krađe i razbojništva distribucija izrečenih sankcija nije tako ujednačena.

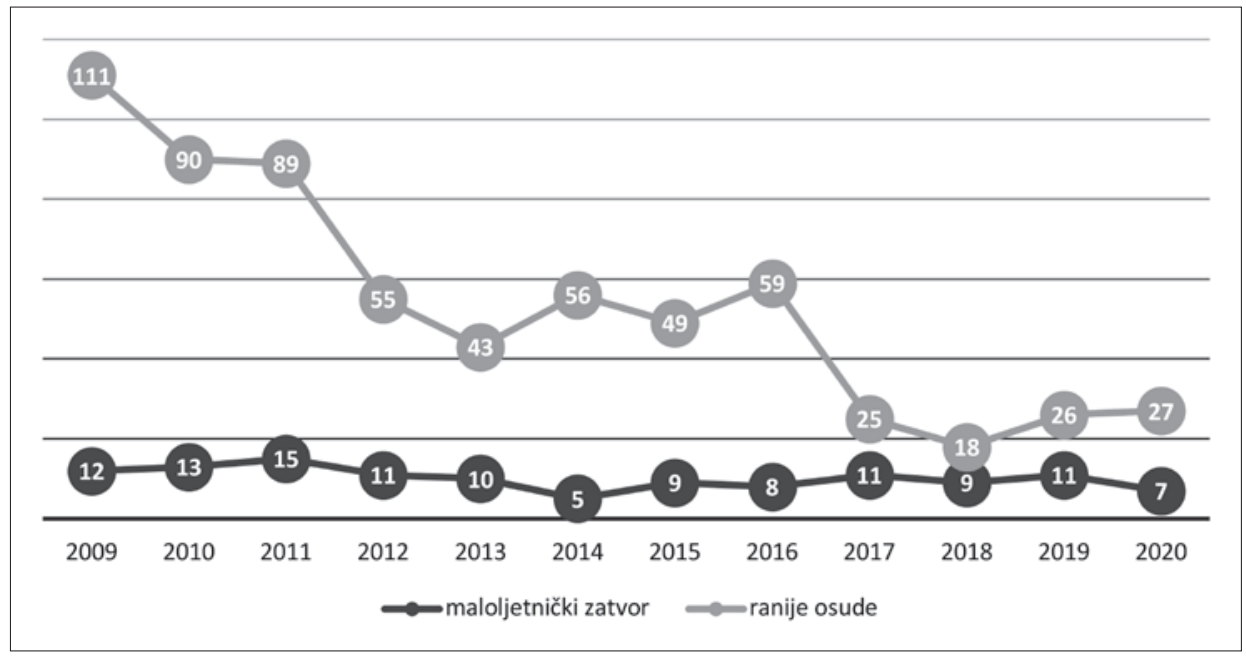

Graf 6: Prikaz ranije osude maloljetnika i maloljetnici kojima je izrečen maloljetnički zatvor od 2009. do 2020. godine

101 Promatrajući ukupan broj osuđenih maloljetnika u 2019. godini za sva kaznena djela, kaznena djela protiv imovine zauzimaju uvjerljivo najveći postotak svih kaznenih djela (52 \%), dok su sljedeća kaznena djela protiv zdravlja ljudi (12 \%). Državni zavod za statistiku, Baza podataka, dostupno na: https://www.dzs.hr. 
Graf 6 prikazuje ukupan broj starijih i mlađih maloljetnika koji su ponovno osuđeni, tj. koji su recidivisti jer su već ranije bili osuđeni za počinjeno kazneno djelo. U istom je grafu dan prikaz ukupnog broja starijih maloljetnika kojima je izrečen maloljetnički zatvor. Iako je varijabla recidiv, tj. ranije osude, korištena u kvalitativnoj analizi pet presuda Županijskog suda u Zagrebu, deskriptivnom analizom (prema dostupnim podacima DZS-a) nije moguće odrediti utjecaj recidiva na izricanje maloljetničkog zatvora. To nije moguće zato što podaci DZS-a pružaju samo uvid u broj ukupno ranije osuđenih maloljetnika kojima su izrečene različite sankcije, a ne samo maloljetnički zatvor. Primjerice, bilo bi netočno zaključiti iz prikazanih podataka u grafu kako je 2018. od ukupno 18 maloljetnika recidivista njih 9 dobilo maloljetnički zatvor jer ih se ne može dovesti u odnos. Broj 18 predstavlja ukupan broj maloljetnika koji su ponovno počinili kazneno djelo (recidivisti) i za koje im je izrečena neka vrsta sankcije, dok se broj 9 odnosi na maloljetnike kojima je izrečen isključivo maloljetnički zatvor, a ne mora biti riječ o tome da su recidivisti. Iz dostupnih podataka DZS-a ne može se utvrditi koliko je od tih 9 maloljetnika kojima je bio izrečen maloljetnički zatvor uistinu bilo recidivista.

Nemogućnost uspostave odnosa između podataka navedenih u Grafu 6 (maloljetnika recidivista i maloljetničkog zatvora) onemogućava određivanje utjecaja recidiva kao faktora na izricanje maloljetničkog zatvora, tj. pridržaja maloljetničkog zatvora. Ostale varijable koje su obrađene u kvalitativnoj analizi (npr. disfunkcionalna obitelj, problematično ponašanje, priznanje...) nisu mogle biti uzete za obradu pri deskriptivnoj analizi jer jednostavno nisu dostupne u podacima DZS-a. Iz tog se razloga uzela samo varijabla recidiva, jer je bila dostupna i željelo se promotriti može li se dovesti u vezu i postaviti odnos između podataka o maloljetnim recidivistima s podacima o maloljetnicima kojima je izrečen maloljetnički zatvor.

\subsection{Zaključno o istraživanju i o kriterijima razgraničenja}

Iz provedene kvalitativne i deskriptivne analize dostupnih podatka te unatoč činjenici da je riječ o vrlo malom broju maloljetnika osuđenih na maloljetnički zatvor, čime je sužena mogućnost provedbe dublje analize kojom bi se mogla testirati polazna hipoteza, već i dostupni podaci prikazani u ovom radu upućuju na nedostatak formalnih (zakonskih) i sudskih kriterija pri odabiru vrste kazne. Ujedno se time nameće pitanje i o (ne)ujednačenosti trenutačne sudske prakse pri odlučivanju i izricanju ovih dviju sankcija (maloljetničkog zatvora / pridržaja maloljetničkog zatvora).

Zbog navedenog, ovaj rad može poslužiti kao poticaj budućim istraživanjima koja bi upotrebom dodatnih varijabli na većem broju slučajeva te unutar dužeg 
razdoblja mogla ponuditi rješenje i smislen odgovor na postavljeno pitanje. U tom smislu predlaže se daljnja provedba istraživanja radi dobivanja empirijski utemeljenog odgovora.

\section{ZAKLJUČAK}

Iako se ovim radom nastojalo uzeti u obzir i analizirati sve relevantne parametre (varijable) dostupne iz provedenog istraživanja koji bi mogli biti važni pri odabiru ovih dviju vrsti kazne (maloljetnički zatvor i pridržaj), prikazani podaci upućuju na nepostojanje jasnih kriterija u sudskoj praksi i na nepostojanje (zakonskih) formalnih kriterija. Primjerice, očito je kako kvalifikacija djela nije jedan od prevalentnih čimbenika pri donošenju odluke o primjeni maloljetničkog zatvora, odnosno njegova pridržaja, što jasno proizlazi iz kvalitativne analize pravomoćno okončanih sudskih predmeta korištenih u ovom istraživanju. Da nedostatak jasnih kriterija nije stvar isključivo sudske prakse već i normativnog okvira, proizlazi iz činjenice i da ZSM navedene kriterije nije definirao, čime je ostavljen (prevelik?) diskrecijski prostor sudovima da takve kriterije odrede sami. Može se pretpostaviti da je takvo rješenje u skladu s intencijom zakonodavca koji je diskrecijski prostor sucima ostavio zbog osiguranja individualizacije kažnjavanja koje je osobito bitno kod maloljetničke delinkvencije. Ipak, takva praksa posljedično dovodi do pravne nesigurnosti, odnosno nejednakosti u postupanju prema maloljetnim počiniteljima te podrivanja načela jednakosti svih pred zakonom (što podrazumijeva i njegovu primjenu). Pritom valja imati na umu da je riječ o ranjivoj društvenoj skupini koja bi stoga trebala biti pošteđena takvih bojazni. Primjerice, može se pojaviti sumnja da će djeca iz funkcionalnih obitelji bolje proći zbog toga što će im se zbog njihova statusa izreći pridržaj maloljetničkog zatora iako bi im se trebao izreći maloljetnički zatvor. Stoga bi zakonodavac i sud trebali osigurati optimalnu ravnotežu između načela individualizacije kažnjavanja i načela lex certa, čime će se s jedne strane ostvariti ključni ciljevi kaznene politike u području maloljetničke delinkvencije, a s druge strane zaštititi ranjive članove društva od nejednakosti i pravne nesigurnosti.

\section{LITERATURA}

\section{Bibliografija}

Aebi, M. F.; Caneppele, S.; Hashimoto, Y. Z.; Jehle, J.-M.; Khan, T. S.; Kühn, O.; Lewis, C.; Molnar, L.; Pórisdóttir, R.; Smit, P.; national correspondents, European Sourcebook of Crime and Criminal Justice Statistics 2021, Series 
UNILCRIM, 2021., dostupno na: https:/wp.unil.ch/europeansourcebook/ printed-editions-2/ (1.6.2021.).https://wp.unil.ch/europeansourcebook/printed-editions- $2 /$

Beccaria, C., On Crimes and Punishments and Other Writings, University of Toronto Press, Toronto, 2008.

Bezić, R., Juvenile Delinquency in the Balkans: A Regional Comparative Analysis based on the ISRD3-Study Findings, Max-Planck-Gesellschaft zur Förderung der Wissenschaften e.V. u suradnji s Duncker \& Humblot, Berlin, 2020.

Bojanić, I., Croatia, u: Dünkel, F.; Grzywa, J.; Horsfield, P.; Pruin, I. (ur.), Juvenile Justice Systems in Europe - Current Situation and Reform Developments, vol. I, Forum Verlag Godesberg, Mönchengladbach, 2011., str. 187-222.

Božićević-Grbić, M.; Roksandić Vidlička, S., Reforma maloljetničkog kaznenog prava i sudovanja, Hrvatski ljetopis za kazneno pravo i praksu, vol. 18, br. 2, 2011., str. 679-715.

Carić, A., Mlađe osobe u kaznenom pravu (počinitelji i žrtve), Pravni fakultet Sveučilišta u Zagrebu, Zagreb, 2002.

Cvitanović, L., Svrha kažnjavanja u suvremenom kaznenom pravu, Hrvatsko udruženje za kaznenopravne znanosti i praksu, Zagreb, 1999.

Cvjetko, B., Criminal Responsibility of Minors in the Republic of Croatia, Revue internationale de droit pénal, vol. 75, br. 1-2, 2004., str. 263-275; dostupno na: https:// www.cairn.info/revue-internationale-de-droit-penal-2004-l-page-263.htm\#.

Cvjetko, B., Zakonska i sudska politika kažnjavanja maloljetnika i mlađih punoljetnika kaznom maloljetničkog zatvora (1998.-2003.), Hrvatski ljetopis za kazneno pravo i praksu, vol. 11, broj 2, 2004., str. 841-865.

Cvjetko, B.; Singer, M., Kaznenopravna odgovornost mladeži u praksi i teoriji, Organizator, Zagreb, 2011.

Derenčinović, D.; Getoš, A.-M., Uvod u kriminologiju s osnovama kaznenog prava, Pravni fakultet Sveučilišta u Zagrebu, Zagreb, 2008.

Dragičević Prtenjača, M.; Bezić, R., Perspektiva uvođenja doktrine doli incapax $u$ hrvatsko maloljetničko kazneno pravo, Macedonian Journal for Criminal Law and Criminology, vol. 25, br. 1, 2018., str. 1-37.

Dünkel, F., Juvenile Justice Systems in Europe, Reform Developments Between Justice, Welfare and "Mew Punitiveness", Kriminologijos studijos, br. 1, 2014., str. 31-76.

Fagan, J.; Kupchik, A., Juvenile Incarceration and the Pains of Imprisonment, Duke Forum for Law \& Social Change, vol. 3, br. 29, 2011., str. 29-61.

Frank, S., Kazneno pravo, Izdavački zavod Jugoslavenske akademije znanosti i umjetnosti, Zagreb, 1950. 
Getoš Kalac, A.; Pribisalić, D., Tamna i svijetla strana tamne brojke kriminala: o izazovima istraživanja nepoznanica i blagoslovu neznanja, Zbornik Pravnog fakulteta u Zagrebu, vol. 70, br. 5, 2020., str. 637-673; https://doi.org/10.3935/zpfz.70.5.03

Hirjan, F.; Singer, M., Komentar Zakona o sudovima za mladež i kaznenih djela na štetu djece i maloljetnika, MUP RH, Zagreb, 1998.

Horvatić, Ž., Rječnik kaznenog prava, Masmedia, Zagreb, 2002.

Horvatić, Ž.; Derenčinović, D.; Cvitanović, L., Kazneno pravo opći dio 2 - Kazneno djelo i kaznenopravne sankcije, Pravni fakultet Sveučilišta u Zagrebu, Zagreb, 2017.

Hrabar, D., Zaštita djece u kaznenom postupku u promišljanjima o pravosuđu naklonjenom djeci, Godišnjak Akademije pravnih znanosti Hrvatske, vol. IX, br. I, 2018., str. 1-28.

Ivičević Karas, E., Pomicanje granica prava na branitelja pod utjecajem europskog kaznenog prava, Hrvatski ljetopis za kazneno pravo i praksu, vol. 22, br. 2, 2015., str. 355-382.

Ivičević Karas, E.; Munivrana Vajda, M., Kazneno pravo i djeca, u: Hrabar, D. (ur.), Prava djece - multidisciplinaran pristup, Pravni fakultet Sveučilišta u Zagrebu, Zagreb, 2016., str. 147-171.

Lechner, S., Najbolji interes maloljetnika u kaznenom pravu, završni specijalistički rad, Pravni fakultet Sveučilišta u Zagrebu, Zagreb, (srpanj) 2021.

Lipsey, M. W.; Howell, J. C.; Kelly, M. R.; Chapman, G.; Carver, D., Improving the Effectiveness of Juvenile Justice Programs: A New Perspective on Evidence-Based Practice, Center for Juvenile Justice Reform, Georgetown Public Policy Institute, Georgetown University, Washington, D.C., 2010.

Novoselec, P., Opći dio kaznenog prava, Pravni fakultet u Osijeku, Osijek, 2016.

Puharić, B.; Radić, I., Primjena načela svrhovitosti u postupanju prema maloljetnicima, Hrvatski ljetopis za kazneno pravo i praksu, vol. 22, br. 2, 2015., str. 635-670.

Radić, I., Hrvatski sustav maloljetničkih sankcija: trenutačno stanje i prijedlozi za promjenu, Hrvatski ljetopis za kaznene znanosti i praksu, vol. 24, br. 1, 2017., str. 83-115.

Radić, I., Sustav maloljetničkih sankcija, doktorska disertacija, Pravni fakultet Sveučilišta u Zagrebu, Zagreb, 2016.

Ricijaš, N., Atribuiranje vlastitog delinkventnog ponašanja nisko rizičnih i visoko rizičnih maloljetnih delikvenata, Kriminologija i socijalna integracija, vol. 17, br. 1., 2009., str. 13-26.

Ricijaš, N., Obilježja maloljetnika koji izvršavaju kaznu maloljetničkog zatvora u Republici Hrvatskoj, Kriminologija i socijalna integracija, vol. 13, br. 1, 2005., str. 89-105. 
Rittossa, D.; Božićević-Grbić, M., Zakon o sudovima za mladež - reformski zahvati i praktične dileme, Hrvatski ljetopis za kazneno pravo i praksu, vol. 19, br. 2, 2012., str. 615-667.

Scott, E.; Steinberg, L., Adolescent Development and the Regulation of Youth Crime, The Future of Children: Juvenile Justice, vol. 18, br. 2, 2008., str. 15-33.

Van der Laan, A.; Eichelsheim, V., Juvenile Adaptation to Imprisonment: Feelings of Safety, Autonomy and Well-Being, and Behaviour in Prison, European Journal of Criminology, vol. 10, br. 4, 2013., str. 424-443.

Zagorec, M., Maloljetnički zatvor u hrvatskom kaznenopravnom sustavu, doktorska disertacija, Pravni fakultet Sveučilišta u Zagrebu, Zagreb, 2019.

Zagorec, M., Problematika postupanja prema maloljetnim počiniteljima kaznenih djela, Policija i sigurnost, vol. 26, br. 4, 2017., str. 283-301.

\section{Pravni akti}

Direktiva (EU)2016/800 Europskog parlamenta i Vijeća o postupovnim jamstvima za djecu koja su osumnjičenici ili optuženici u kaznenim postupcima.

Direktiva 2012/13/EU Europskog parlamenta i Vijeća o pravu na informiranje u kaznenom postupku

Direktiva 2012/29/EU Europskog parlamenta i Vijeća o uspostavi minimalnih standarda za prava, potporu i zaštitu žrtava kaznenih djela

Direktiva 2013/48/EU Europskog parlamenta i Vijeća o pravu na pristup odvjetniku u kaznenom postupku i u postupku na temelju europskog uhidbenog naloga te o pravu na obavješćivanje treće strane u slučaju oduzimanja slobode i na komunikaciju s trećim osobama i konzularnim tijelima

Direktiva(EU) 2011/93 Europskog parlamenta i Vijeća o suzbijanju seksualnog zlostavljanja i seksualnog iskorištavanja djece i dječje pornografije

Europska konvencija za zaštitu ljudskih prava i temeljenih sloboda, Narodne novine, br. 18/97, 6/99, 14/02, 13/03, 9/05, 1/06, 2/10.

Konvencija o pravima djeteta iz 1989.

Opća preporuka br. 10, CRC/C/GC/10, 25. travnja 2007.; dostupna na: https:// www2.ohchr.org/english/bodies/crc/docs/CRC.C.GC.10.pdf.

Pravila UN za zaštitu maloljetnika lišenih slobode - "Havanska ili JDL pravila", 1990.

Pravilnik o načinu izvršavanja kazne maloljetničkog zatvora u kaznenom i prekršajnom postupku, Narodne novine, br. 57/13.

Preporuka Vijeća ministara CM/Rec (2008)11 o Europskim pravilima za maloljetne prijestupnike osuđene na sankcije ili mjere (VE). 
Preporuka Vijeća ministara Rec(2003)20 o novim načinima suočavanja s maloljetničkom delinkvencijom i ulogom maloljetničkog pravosuđa (VE).

Preporuka Vijeća ministara Rec(2005)5 o pravima djece koja žive u ustanovama Rezolucija 1530(2007) o djeci žrtvama kaznenih djela: suzbijanje svih oblika nasilja, izrabljivanja i zlouporaba (VE).

Smjernice UN za prevenciju maloljetničke delinkvencije - "Rijadske smjernice", 1990.

Smjernice UN-a o pravosuđu u predmetima koji uključuju djecu kao žrtve i svjedoke kaznenih djela - Rezolucija Gospodarskog i socijalnog vijeća 2005/20 i dr.

Smjernice Vijeća ministara (VE) o pravosuđu prilagođenom djeci (Guidelines of the Committee of Ministers of the Council of Europe on child-friendly justice), 2010.

Standardna minimalna pravila UN za provođenje sudskih postupaka prema maloljetnicima, tzv. Pekinška pravila (1985), A/RES/40/33; dostupna na: https://www.refworld.org/docid/3b00f2203c.html

Standardna minimalna pravila UN-a, A/RES/40/33; čl. 4., točk. 4.1., str. 207 dostupna na: https://www.refworld.org/docid/3b00f2203c.html (10.6.2020.).

\section{Nacionalni zakoni}

Kazneni zakon, Narodne novine, br. 125/11, 144/12, 56/15, 61/15, 101/17, 118/18, 126/19, 84/21.

Zakon o izvršavanju kazne zatvora, Narodne novine, br. 14/21.

Zakon o izvršavanju sankcija izrečenih maloljetnicima za kaznena djela i prekršaje, Narodne novine, br. 133/12.

Zakon o kaznenom postupku, Narodne novine, br. 152/08, 76/09, 80/11, 121/11, 91/12, 143/12, 56/13, 145/13, 152/14, 70/17, 126/19, 126/19.

Zakon o sudovima za mladež, Narodne novine, br. 84/11, 143/12, 148/13, 56/15, 126/19.

\section{Presude ESLJP}

Presuda ESLJP, T. protiv Ujedinjenog Kraljevstva (T. v. United Kingdom), zahtj. br. 24724/94, od dana 16. prosinca 1999., § 18, 27; dostupna na: https://hudoc. echr.coe.int/eng\#\{\%22itemid\%22:[\%22001-58593\%22]\} i na https://hudoc. echr.coe.int/eng\# \{\%22fulltext\%22:[\%22T.\%20and\%20V.\%20v.\%20Uni- 
ted $\% 22], \% 22$ documentcollectionid2\%22:[\%22GRANDCHAMBER\%22, \%22CHAMBER\%22],\%22itemid\%22:[\%22001-58593\%22]\}

Presuda ESLJP, Adamkiewicz protiv Poljske (zahtj. br. 54729/00), od dana 2. ožujka 2010. (konačna 4. listopada 2010.); dostupna na: https://hudoc.echr.coe.int/ eng\#\{\%22itemid\%22:[\%22001-97477\%22]\}

Presuda ESLJP, Blokhin protiv Rusije (Zahtj. br. 47152/06), od dana 23. ožujka 2016.; dostupna na: https://hudoc.echr.coe.int/eng\#\{\%22fulltext\%22:[\%22Blokhin\%22],\%22itemid\%22:[\%22001-161822\%22]\}

Presuda ESLJP, Coşelav protiv Turske (Zahtj. br. 1413/07), od dana 9.10.2010. (konačna 18. ožujka 2013.); dostupna na: https://hudoc.echr.coe.int/eng\#\{\%22fulltext\%22:[\%22\%C3\%87O\%C5\%9EELAV\%20v.\%20TURKEY\%22],\%22documentcollectionid2\%22:[\%22GRANDCHAMBER\%22,\%22CHAMBER\%22],\%22itemid\%22:[\%22001-113767\%22]\}

Presuda ESLJP, Panovits v. Cyprus, (zahtj. br. 4268/04), od dana 11. prosinca 2008. (konačna 11. ožujka 2009.)

Presuda ESLJP, Salduz protiv Turske.- Presuda ESLJP Salduz protiv Turske (Zahtj. br. 36391/02), od dana 27. studenog 2008.

Presuda ESLJP, V. protiv Ujedinjenog Kraljevstva (V. v. United Kingdom); zahtj, br. 24888/94 od dana 16. prosinca 1999., §17, 19, 29; dostupna na: https://hudoc. echr.coe.int/eng\#\{\%22itemid\%22:[\%22001-58594\%22]\}

\section{Izvješća}

Državni zavod za statistiku, Baza podataka, dostupno na: https://www.dzs.hr. Izvješće Državnog zavoda za statistiku, br. 1651/2019., Maloljetni počinitelji kaznenih djela, prijave, optužbe i osude u 2018.

Priopćenje Državnog zavoda za statistiku - Maloljetni počinitelji kaznenih djela prema vrsti odluke u 2019.

\section{Novinski članci}

Marić Banje, K., Tko je odgovoran? Novi detalji o smrti mladića koji je s teškim ozljedama prebačen iz zatvora u splitski KBC gdje je umro - Oglasili se DORH i Ministarstvo pravosuđa; Jutarnji list, od dana 27. kolovoza 2019.; dostupno na: https://www. jutarnji.hr/vijesti/hrvatska/novi-detalji-o-smrti-mladica-koji-je-s-teskim-ozljedama-prebacen-iz-zatvora-u-splitski-kbc-gdje-je-umro-oglasili-se-dorh-i-ministarstvo-pravosuda-9286304. 
Summary

\section{Marta Dragičević Prtenjača* \\ Reana Bezić** \\ Marina Zagorec ${ }^{* * *}$}

\section{THE CROATIAN JUVENILE JUSTICE SYSTEM THROUGH CASE LAW CONCERNING JUVENILE INCARCERATION AND RESERVATION OF THE RIGHT TO IMPOSE THE SENTENCE OF JUVENILE INCARCERATION - ARE THERE CRITERIA OR DO THE COURTS HAVE TOTAL DISCRETION?}

Juvenile courts throughout Croatia impose sanctions on juvenile offenders (juveniles). Their decision-making often raises issues of their discretion in deciding on the application of juvenile sanctions, especially juvenile incarceration and its suspension (Reservation of the Right to Impose the Sentence of Juvenile Incarceration), which can be a significant issue in terms of the uniformity of the juvenile case law. Therefore, the research sought to examine whether there are certain formal criteria for distinguishing the application of juvenile incarceration from its suspension (Reservation of the Right to Impose the Sentence of Juvenile Incarceration), or if there are criteria that judges use when deciding when and in which cases to apply juvenile imprisonment, and when its suspension. Consequently, the following Hypothesis is set: There are criteria for distinguishing the application of juvenile incarceration from the suspension of sentence of juvenile incarceration (Reservation of the Right to Impose the Sentence of Juvenile Incarceration). Normative - descriptive, qualitative and descriptive analyses were used to test the hypothesis in the research.

Keywords: juvenile incarceration, suspended sentence (Reservation of the Right to Impose the Sentence of Juvenile Incarceration), sentencing, the discretion of courts in decision making

* Marta Dragičević Prtenjača, Ph. D., Associate Professor, Faculty of Law, University of Zagreb, Trg Republike Hrvatske 14, 10000 Zagreb; marta. dragicevic@pravo.hr;

ORCID ID: orcid.org/0000-0001-9666-4765

** Reana Bezić, Ph. D., Assistant, Faculty of Law, University of Zagreb, Trg Republike Hrvatske 14, 10000 Zagreb; rbezic@pravo.hr;

ORCID ID: orcid.org/0000-0002-1299-0860

*** Marina Zagorec, Ph. D., Head of the City Office for Property Affairs, Trg Stjepana Radića 1, 10000 Zagreb; marina.zagorec@zagreb.hr;

ORCID ID: orcid.org/0000-0001-9392-8155 